\title{
Transcriptional regulation of adipogenesis
}

\author{
Evan D. Rosen, ${ }^{1-3}$ Christopher J. Walkey, ${ }^{1}$ Pere Puigserver, ${ }^{1}$ and Bruce M. Spiegelman ${ }^{1,3}$ \\ ${ }^{1}$ Dana-Farber Cancer Institute and Department of Cell Biology, Harvard Medical School, Boston, Massachusetts 02115 USA; \\ ${ }^{2}$ Diabetes Unit, Massachusetts General Hospital, Boston, Massachusetts 02114 USA
}

The past twenty years have seen great strides in our understanding of the molecular regulation of differentiation for a whole host of specific cell types. The development of muscle, bone, pituitary, and several hematopoeitic lineages have all been probed using a variety of biochemical and genetic means, and such studies have yielded both general and tissue-specific insights. Adipose tissue has also been the subject of intense scrutiny, for two important reasons. First, the establishment of immortal preadipocyte cell lines (see below) provided an experimentally accessible system in vitro, many features of which faithfully recapitulate this process in vivo. These features include morphological changes, cessation of cell growth, expression of many lipogenic enzymes, extensive lipid accumulation, and the establishment of sensitivity to most or all of the key hormones that impact on this cell type, including insulin. The second reason why adipose tissue has received so much attention is that this tissue provides a critical link in maintaining systemic energy balance. The ongoing explosion in the incidence of obesity and its ugly stepsister, type 2 diabetes, has focused attention on all aspects of adipocyte biology, including adipogenesis (Must et al. 1999).

A wealth of observations on the development of adipose tissue in vivo in a variety of species have been recorded throughout the past century. Early on it was noted that fat develops in many different sites scattered throughout the body, generally occurring in areas composed of loose connective tissue, such as the subcutaneous layers between the muscle and dermis. However, fat deposits also form around the heart, kidneys, and other internal organs. The diffuse nature of adipose differentiation in vivo has made it difficult to dissect out regions of presumptive precursor cells from embryos and study these ex vivo. Similarly, a lack of molecular markers identifying the preadipocytic state has hampered investigations in living animals.

These difficulties were partially circumvented in the 1970's when Green and his colleagues established immortal fibroblast lines that readily differentiated into

${ }^{3}$ Corresponding authors.

E-MAIL edrosen@massmed.org; FAX (617) 632-5363.

E-Mail bruce_spiegelman@dfci.harvard.edu; FAX (617) 632-4655. adipocytes when appropriate hormonal inducers were added (Green and Kehinde 1974, 1975, 1976). These lines, designated 3T3-L1 and 3T3-F442A, were isolated from nonclonal Swiss 3T3 cells and are already committed (or determined) to the adipocytic lineage. When treated with an empirically-derived prodifferentiative regimen that includes CAMP, insulin, and glucocorticoids, they undergo differentiation to mature fat cells over a 4-6 day period. Subsequently, committed preadipocyte lines have been derived independently by others (Negrel et al. 1978; Chapman et al. 1984); despite minor differences in their optimal differentiation conditions they behave very similarly to 3T3-L1 and 3T3-F442A cells.

More recently, studies have been performed using pluripotent stem cells that can be induced to yield adipose tissue in addition to several other lineages. Mesenchymal stem cell lines can be differentiated to muscle, cartilage, and fat depending upon the chosen conditions (Taylor and Jones 1979), and marrow-derived stromal cells can be induced to form both bone cells and fat cells (Pittenger et al. 1999). Although stem cell technology is developing rapidly, their recent introduction and the complexity inherent in these systems has prevented them from being extensively used in the adipogenesis field. Almost all work on adipogenesis has utilized either the aforementioned predetermined clonal cell lines or cultured preadipocytes isolated from the stromal-vascular fraction of dissociated fat pads.

Despite the many insights gleaned from these models, several caveats must be kept in mind when interpreting results. First, these cell lines are differentiated to white adipose tissue (WAT) almost exclusively. Mammals have a second type of fat cell called the brown adipocyte, which serves primarily to dissipate energy instead of storing it (Lowell and Flier 1997). This energy wasting is accomplished by a brown adipose tissue (BAT)-specific protein called uncoupling protein-1 (UCP-1), which generates heat by dissipating the proton gradient that is established across the inner mitochondrial membrane during the passage of electrons along the respiratory chain (Garlid et al. 1998). In physiological terms, brown fat functions in adaptation to cold and as protection against obesity. Cultured cell models of BAT do exist, but most of these do not mimic their endogenous ortholog quite as 
well as white adipocyte models do, and studies on brown fat have lagged as a result.

There are other drawbacks to the exclusive use of established preadipocytic cell lines in studies of adipogenesis, including their aneuploid status, which may influence their competence to undergo differentiation, and the fact that they exist out of the context of their normal extracellular matrix and supporting structures. Another very important limitation is that they have not, to date, allowed an assessment of depot-specific differences in fat cell behavior. In vivo, WAT can be found in a variety of locations, including perigonadal, omental, retroperitoneal, and subcutaneous depots. Preadipocytes isolated from different areas have different adipogenic potential, the basis for which is completely unknown (Djian et al. 1985; Adams et al. 1997a; Lefebvre et al. 1998). Additionally, the metabolic behavior of mature fat cells differs from depot to depot. There are, for example, known differences in the lipolytic response to adrenergic stimulation between visceral and subcutaneous fat pads (Ostman et al. 1979; Morimoto et al. 1997). Regional differences in fat cell behavior can have very important clinical consequences; humans (typically male) with increased visceral adiposity have a higher risk of insulin resistance, dyslipidemia, and cardiovascular disease than those of equivalent weight but a higher degree of subcutaneous adiposity (Reaven 1988).

\section{Adipocyte development in vitro}

Adipogenesis in vitro follows a highly ordered and well characterized temporal sequence. Initially, there is growth arrest of proliferating preadipocytes, usually achieved in cultured cell lines after contact inhibition, although experiments using very low density plating in serum-free medium (Gregoire et al. 1998) or in suspension in methylcellulose (Pairault and Green 1979) demonstrate that cell-cell contact is not an absolute requirement for growth arrest to occur. In cultured cell models, initial growth arrest is induced by the addition of a prodifferentiative hormonal regimen and is followed by one or two additional rounds of cell division known as clonal expansion. This process ceases coincident with the expression of the key transcription factors peroxisome proliferator-activated receptor $\gamma(\operatorname{PPAR} \gamma)$ and CCAAT/enhancer binding protein $\alpha(\mathrm{C} / \mathrm{EBP} \alpha)$, about which much more will be said later (Shao and Lazar 1997; Morrison and Farmer 1999). The induction of these two proteins is characterized by a second, permanent period of growth arrest followed by expression of the fully differentiated phenotype. The exact mechanisms by which PPAR $\gamma$ and $\mathrm{C} / \mathrm{EBP} \alpha$ bring about this change is unclear, but several important clues have surfaced recently. In nonconfluent 3T3-F442A cells, activation of PPAR $\gamma$ correlates with loss of DNA binding activity of E2F/DP, a central transcriptional player in the regulation of many genes involved in cell growth (Altiok et al. 1997). This alteration in E2F/DP binding is secondary to a decrease in the protein phosphatase PP2A, which results in increased phosphorylation of DP-1, blocking DNA binding. The E2F family of transcription factors promotes cell division in a variety of models of cellular growth and differentiation.

In these systems, E2F activity can also be inhibited by the binding of the retinoblastoma protein $(\mathrm{Rb})$, which has been shown to be an important factor in the differentiation of many cell types, including muscle, nerve, and hematopoeitic lineages (Black and Azizkhan-Clifford 1999; Kaelin 1999). Studies on fat cell development are consistent with a role for $\mathrm{Rb}$ in the differentiation of this cell type as well. Thus, SV40 large T antigen, which binds to and sequesters $\mathrm{Rb}$, inhibits adipogenesis (Higgins et al. 1996). Similarly, $\mathrm{Rb}^{-1-}$ cells are deficient in their adipogenic capacity until rescued by an Rb-expressing transgene (Chen et al. 1996; Richon et al. 1997). Physical and functional interactions between $\mathrm{Rb}$ and C/EBP proteins, especially C/EBP $\alpha$ and $\beta$, have also been demonstrated in both white and brown adipocyte model systems (Chen et al. 1996; Puigserver et al. 1998a). Interestingly, $\mathrm{Rb}^{-/-}$cells express PPAR $\gamma$, and the addition of a ligand for this receptor is sufficient to overcome the block in adipogenesis displayed by these cells (Hansen et al. 1999). This result implies that PPAR $\gamma$ acts downstream of $\mathrm{Rb}$ in promoting growth arrest and the establishment of the differentiated adipocyte phenotype.

Additional mechanisms to account for PPAR $\gamma$ and $\mathrm{C} / \mathrm{EBP} \alpha$-induced growth arrest have been proposed. In 3T3-L1 cells, the shift from dividing preadipocytes to growth-arrested cells to fully differentiated fat cells was associated with changes in the expression of several cyclin-dependent kinase inhibitors, including p18 (INK4c), p21 (Waf1/Cip1), and possibly p27 (Kip1) (Morrison and Farmer 1999). The expression of PPAR $\gamma$ in NIH-3T3 fibroblasts specifically induced $\mathrm{p} 18$ and $\mathrm{p} 21 . \mathrm{C} / \mathrm{EBP} \alpha$ is also known to have antimitotic properties (Umek et al. 1991), some of which are exerted through expression and stabilization of $\mathrm{p} 21$ (Timchenko et al. 1996).

Although growth arrest is virtually a sine qua non of the differentiation process, there is some debate about the requirement for clonal expansion in vivo. Several studies have shown that the inhibition of cell division in cultured preadipocytic lines clearly blocks their subsequent differentiation. Primary human preadipocytes, on the other hand, have been shown to undergo differentiation normally even if pretreated with alkylating agents that powerfully inhibit mitosis (Entenmann and Hauner 1996). Although it is possible that postconfluent mitoses are an artifact of the cultured cell line system, it is equally possible that preadipocytes isolated from fat pads have undergone the requisite cell divisions in vivo, and are thus already competent to undergo terminal differentiation.

This process of terminal differentiation occurs over several days in cultured cell lines. A second, permanent state of growth arrest occurs followed by the accumulation of phenotypic markers of the mature adipocyte. The earliest events include a morphological rounding up of the fibroblast-like preadipocytes and the expression of mRNAs including lipoprotein lipase and the transient induction of the transcriptional components $\mathrm{C} / \mathrm{EBP} \beta$ and C/EBPS (MacDougald and Lane 1995; Darlington et 
al. 1998). These earliest events are followed by the appearance of PPAR $\gamma$ and $\mathrm{C} / \mathrm{EBP} \alpha$, which activate de novo or enhanced expression of most or all of the genes that characterize the adipocyte phenotype. These genes include (to name just a few) glycerophosphate dehydrogenase, fatty acid synthase, acetyl CoA carboxylase, malic enzyme, Glut 4, the insulin receptor, and aP2 (the adipocyte-selective fatty acid binding protein) (Spiegelman et al. 1993). Throughout this process, lipid-laden droplets begin to appear in the cytoplasm, and over time they become quite large and often coalesce into one or a few major droplets.

\section{Transcriptional control of adipose differentiation}

Functionally, cellular differentiation can be thought of as a shift in gene expression patterns, such that transcripts that determine the primitive, multipotent state give way to those that define the final phenotype. Morphological changes, such as alterations in cell shape and the accumulation of lipid that accompany adipogenesis, result from the actions of genes that are induced as the cells differentiate. In this sense, changes in transcription factor expression and activity define the process of differentiation. Studies in preadipocytic and fibroblastic cultured cell lines have yielded a wealth of data on the transcriptional cascade that drives adipogenesis. More recently, the models constructed from these observations have been tested in vivo using transgenic and knockout mouse technology, with occasional surprising results.

Three classes of transcription factor have been identified that directly influence fat cell development. These include PPAR $\gamma, \mathrm{C} / \mathrm{EBPs}$, and the basic helix-loop-helix family (ADD1/SREBP1C). The following sections will discuss experimental results that have been obtained in vitro and in vivo, and will attempt to build a comprehensive model of the transcriptional control of adipogenesis.

\section{PPAR $\gamma$}

PPAR $y$ is a member of the nuclear hormone receptor superfamily, and, like many members of this class of transcription factor, PPAR $\gamma$ must heterodimerize with another nuclear hormone receptor (the retinoid X receptor, or RXR) to bind DNA and be transcriptionally active. PPAR $\gamma$ exists as two protein isoforms generated by alternative promoter usage and alternative splicing. PPAR $\gamma 2$ is 30 amino acids longer at the amino terminus than PPAR $\gamma 1$, and is the dominant isoform found in fat cells (Tontonoz et al. 1995). PPAR $\gamma 1$ is present at lower levels in adipose tissue and in a variety of other cell types, including macrophages, type II pneumocytes, and the epithelia of colon, bladder, breast, and prostate (Mansen et al. 1996; Michael et al. 1997; Mueller et al. 1998; Sarraf et al. 1998; Tontonoz et al. 1998).

$\operatorname{PPAR} \gamma$ was cloned independently by several groups with different goals in mind. While searching for homologues to PPAR $\alpha$ (then simply called PPAR), three groups found two additional family members in Xenopus and mice that were called PPAR $\beta$ (also called PPAR $\delta$, NUC1, and FAAR) and PPAR $\gamma$ (Dreyer et al. 1992; Zhu et al. 1993; Kliewer et al. 1994). These receptors were shown to activate the acyl CoA oxidase promoter in response to a variety of xenobiotic and hypolipidemic agents. In contrast, members of our own laboratory were looking for transcription factors that promoted fat cell development. Using the adipose cell-selective fatty acid binding protein aP2 as a model, a $5^{\prime}$ flanking region was identified 5 $\mathrm{kb}$ upstream of the start of transcription. This enhancer was shown to be sufficient to direct gene expression from a minimal promoter specifically to fat cells in culture and in transgenic mice (Graves et al. 1992). Further definition of this region revealed cis-acting elements termed ARE6 and ARE7 that bound to a factor called ARF6. Cloning of this factor identified it as a heterodimer consisting of PPAR $\gamma$ and its obligate partner, RXR (Tontonoz et al. 1994a,b).

In addition to its role in inducing aP2 expression, PPAR $\gamma$ activates the promoters of many other fat-cell specific genes. The expression of PEPCK in fat cells, for example, requires PPAR $\gamma$ binding (Tontonoz et al. 1995). This is true in cultured adipocytes as well as in vivo, where the analysis of transgenic mice has demonstrated that activation of this promoter in fat is dependent on a PPAR $\gamma$ binding site, while expression in other tissues is not (Devine et al. 1999).

Nuclear hormone receptor superfamily members are ligand-activated transcription factors, and PPAR $\gamma$ is no exception. PPAR $\gamma$ can be activated by synthetic compounds called thiazolidinediones (TZDs), which are used clinically as antidiabetic agents (Lehmann et al. 1995). These compounds were developed as drug candidates to treat hyperlipidemia and insulin resistance without knowledge of their mechanism of action; only later was their link to PPAR $\gamma$ discovered. They bind to PPAR $\gamma$ with reasonably high affinity $\left(\mathrm{K}_{\mathrm{D}}=50-700 \mathrm{nM}\right)$, and the rank order of their potency in reversing hyperglycemia in vivo is generally well correlated with their binding affinity for PPAR $\gamma$ (Lehmann et al. 1995). As might be expected of a PPAR $\gamma$ ligand, treatment of preadipocytes with TZDs increases both the extent and the rate of adipogenesis (Kletzien et al. 1992; Sandouk et al. 1993). This occurs in vivo as well as in vitro, although it is not clear if the adipogenic potential of these agents is related to their antidiabetic actions.

Despite the utility of TZDs as investigative and therapeutic tools, no endogenous PPAR $\gamma$ ligand has been discovered with clear physiological relevance. The search for such a compound has, in fact, identified some natural ligands, including 15 deoxy- $\Delta^{12,14}$ prostaglandin $J_{2}$, or $15 \mathrm{dPGI}_{2}$ (Forman et al. 1995; Kliewer et al. 1995). This eicosanoid is able to bind to and activate PPAR $\gamma$, and can promote adipogenesis when added to cultured fibroblasts. Other natural fatty acids, including linoleic acid, can bind PPAR $\gamma$ as well (Forman et al. 1997; Kliewer et al. 1997). However, it is important to note that all of these natural ligands bind with affinities in the $\mathrm{K}_{\mathrm{D}}=2$ $50 \mu \mathrm{m}$ range, well below the published affinities of most other nuclear hormone receptors for their ligands. Addi- 
tionally, $15 \mathrm{dPG}_{2}$ has been shown to potently inhibit IкB kinase (Castrillo et al. 2000; Rossi et al. 2000); this activity accounts for many if not all of the anti-inflammatory effects of this compound in murine macrophages and cultured cell lines. This provokes concern that some of the biological effects of this compound that have been ascribed to PPAR $\gamma$ activation may in fact be mediated via other routes. Thus, the search for a natural, high affinity PPAR $\gamma$ ligand continues in a variety of academic and commercial laboratories.

The first "gain-of-function" experiments that linked PPAR $\gamma$ to fat cell development utilized retrovirally-expressed PPAR $\gamma$ in nonadipogenic, fibroblastic cells. Using the relatively nonspecific ligands available at the time, activation of PPAR $\gamma$ was shown to strongly induce adipogenesis (Tontonoz et al. 1994c). These observations have been made more robust through the use of high affinity, selective PPAR $\gamma$ agonists, such as TZDs (Kletzien et al. 1992; Sandouk et al. 1993). The effect of PPAR $\gamma$ activation is seen on all aspects of the mature fat cell phenotype, including morphological changes, lipid accumulation, and the acquisition of insulin sensitivity. PPAR $y$ is such a potent inducer of adipogenesis, in fact, that it can promote the transdifferentiation of cultured myoblasts to adipocytes, particularly when coexpressed with $\mathrm{C} / \mathrm{EBP} \alpha$ (Hu et al. 1995). Finally, a role for PPAR $\gamma$ in adipogenesis in humans is suggested by the results of ongoing clinical trials of PPAR $\gamma$ agonists in liposarcoma, a malignant tissue of adipose origin. These tumors exhibit a strong differentiative response to these agents (Tontonoz et al. 1997); whether this leads to improved patient outcome is currently the subject of active investigation.

Several loss-of-function studies in adipogenesis have now been performed. These argue convincingly that PPAR $\gamma$ is necessary as well as sufficient to promote fat cell differentiation. The traditional approach to answering this question involves the production of a mouse with homozygous targeted disruptions of the relevant gene. Mice made nullizygous for PPAR $\gamma$ do not survive past embryonic day 10-10.5, however, because of a defect in placental development (Barak et al. 1999; Kubota et al. 1999). This occurs prior to the formation of identifiable fat cells in mice. Three separate labs circumvented this problem in different ways. One approach was to create chimeric mice derived from both wild-type ES cells and cells with a homozygous deletion of PPAR $\gamma$ (Rosen et al. 1999). This strategy allows one to measure the contribution of PPAR $\gamma$ null cells to adult tissues in healthy animals. By showing exclusion of null cells from WAT, but not several other tissues, PPAR $\gamma$ was demonstrated to be required for adipogenesis in vivo. PPAR $\gamma$ is also required for the differentiation of adipose cells from ES cells (Rosen et al. 1999) or from embryonic fibroblasts in vitro (Kubota et al. 1999). Another approach was to create chimeric embryos using a combination of wildtype tetraploid cells that allow rescue of the placental defect and PPAR $\gamma$-null cells that are the sole contributor to the embryo proper (Barak et al. 1999). Using this strategy, one homozygous mutant mouse developed to term, though it died shortly after birth. Nevertheless, it was clear that this neonate lacked significant brown fat depots. No conclusion was drawn regarding WAT, as this tissue develops postnatally in mice, and this animal died prior to the time it would have formed. Interestingly, animals with only one PPAR $\gamma$ allele exhibit resistance to diet-induced obesity, although this results at least in part from elevated serum leptin levels and decreased food intake in these mice (Kubota et al. 1999; Miles et al. 2000).

The results of these genetic studies have been complemented by experiments using recently developed pharmacological inhibitors of PPAR $\gamma$. These studies demonstrate that PPAR $\gamma$ antagonists can reduce adipogenesis induced by the usual hormonal treatments or by agonist ligands of PPAR $\gamma$ (Oberfield et al. 1999; Wright et al. 2000). In addition, a dominant-negative allele of PPAR $\gamma$ has been developed that binds to ligand and DNA normally, but that fails to interact with several coactivator proteins (see below) (Gurnell et al. 2000). The expression of this allele in human preadipocytes blocks TZD-induced differentiation.

Heterozygous mutations in PPAR $\gamma$ have also been discovered recently in a small number of patients with severe insulin resistance (Barroso et al. 1999). The mutant alleles in these patients have been shown to exhibit dominant-negative activity when expressed in vitro as well. Interestingly, these patients have normal fat content, indicating that the dosage of PPAR $\gamma$ required for fat cell formation in humans might be different from that required for normal insulin sensitivity.

\section{C/EBP family}

The C/EBPs belong to the basic-leucine zipper class of transcription factors. Six isoforms have been described, all of which act as homo- and/or heterodimers formed via a highly conserved bZIP domain (Lekstrom-Himes and Xanthopoulos 1998). Their tissue distribution is not restricted to fat cells, and a role for C/EBP proteins has been demonstrated in the terminal differentiation of granulocytes (Zhang et al. 1997) and hepatocytes (Wang et al. 1995; Flodby et al. 1996), for example. C/EBPs also play an important role in resistance to infection (Yamanaka et al. 1997) and the tissue response to injury (Flodby et al. 1996) in addition to transactivating a wide variety of target genes.

$\mathrm{C} / \mathrm{EBP}$ s can be regulated at many levels, including transcriptionally, as measured by mRNA levels in cells. Indeed, cAMP, a well-known inducer of adipogenesis in vitro and a component of most prodifferentiative regimens, can enhance expression of both $\mathrm{C} / \mathrm{EBP} \alpha$ and C/EBP $\beta$ (Cao et al. 1991; Tang et al. 1999). In addition, alternative translational start sites yield multiple isoforms of some of the C/EBPs, including C/EBP $\alpha$ and $\beta$. For example, the $42-\mathrm{kD} \mathrm{C} / \mathrm{EBP} \alpha$ isoform is a stronger transcriptional activator than the $30-\mathrm{kD}$ isoform, and the p42/p30 ratio increases during the course of adipogenesis (Lin et al. 1993). Although experiments such as these do not prove that translation is a regulated step in fat cell formation, they at least open that possibility. Similarly, 
the amount of the $20-\mathrm{kD}$ inhibitory isoform of $\mathrm{C} / \mathrm{EBP} \beta$ decreases during adipogenesis relative to the $32-\mathrm{kD}$ active isoform (Bachmeier and Loffler 1997). Post-translational regulation of C/EBPs, particularly changes in phosphorylation, can modify the activity of C/EBP proteins as well. Finally, the activity of C/EBPs can be modulated by the presence of other family members; $\mathrm{C} / \mathrm{EBP} \zeta$ (also known as CHOP or Gadd 153), for example, can not bind DNA by itself but does dimerize with other C/EBPs, thus acting as a natural dominant-negative inhibitor of C/EBP activity (Ron and Habener 1992).

Regulated expression is seen for several C/EBP family members during adipogenesis, and recent gain- and lossof-function studies indicate that these proteins have a profound impact on fat cell development. In cultured preadipocytic cell lines that have been induced to differentiate, C/EBP $\beta$ and $\delta$ mRNA and protein levels rise early and transiently (Cao et al. 1991; Yeh et al. 1995). $\mathrm{C} / \mathrm{EBP} \alpha$, on the other hand, is induced later in the differentiation process, slightly preceding the induction of most of the end-product genes of fat cells. The inhibitory $\mathrm{C} / \mathrm{EBP} \zeta$, on the other hand, is suppressed during the induction of differentiation, but returns when differentiation has progressed almost to completion (Darlington et al. 1998). This isoform may therefore act as a brake on the adipogenic program after important events have been initiated.

The proadipogenic role of $\mathrm{C} / \mathrm{EBP} \beta$ and $\delta$ was originally made clear in gain-of-function experiments in vitro. Ectopic expression of $C / E B P \beta$ is sufficient to induce the differentiation of 3T3-L1 cells without the addition of hormonal inducers; similar experiments with C/EBPS reveal that prodifferentiative agents are still required, but adipogenesis is accelerated (Yeh et al. 1995). C/EBP $\beta$ may also be able to determine cells to the adipocytic lineage as well as promote their differentiation; ectopic expression of C/EBP $\beta$ (but not $\delta$ ) in NIH-3T3 fibroblasts is permissive for adipogenesis in the presence of hormonal inducers (Wu et al. 1995). Embryonic fibroblasts lacking either C/EBP $\beta$ or $\delta$ showed slight reductions in adipogenic potential, but cells lacking both $\mathrm{C} / \mathrm{EBP} \beta$ and $\delta$ were severely impeded from developing into adipocytes (Tanaka et al. 1997). In vivo results from mice lacking these factors are more ambiguous, although they still generally support a role in fat cell development. Mice lacking either $\mathrm{C} / \mathrm{EBP} \beta$ or $\delta$ have normal WAT, although their BAT shows reductions in lipid accumulation and UCP-1 expression. Mice that lack both C/EBP $\beta$ and $\delta$, however, have a more dramatic phenotype. Approximately $85 \%$ of these animals die in the perinatal period of unknown causes; the remaining $15 \%$ that survive have sharply reduced BAT and smaller decreases in WAT (Tanaka et al. 1997). Interestingly, the reduction in BAT appears to be a result of reduced lipid accumulation, whereas the reduction in WAT is reported to involve hypoplasia, with normal size, morphology, and gene expression profiles in those white adipocytes that do develop.

The involvement of $\mathrm{C} / \mathrm{EBP} \alpha$ in adipogenesis is also strongly supported by in vitro data. Overexpression of $\mathrm{C} / \mathrm{EBP} \alpha$ in 3T3-L1 preadipocytes induces their differen- tiation into mature fat cells (Freytag et al. 1994; Lin and Lane 1994), and the expression of C/EBP $\alpha$ antisense RNA in these cells blocks this process (Lin and Lane 1992). Animals that carry a homozygous deletion of the $\mathrm{C} / \mathrm{EBP} \alpha$ gene have dramatically reduced fat accumulation in WAT and BAT pads (Wang et al. 1995). However, since these mice succumb to hypoglycemia within the first week of life as a result of a failure to activate gluconeogenesis in the liver, their reduced adiposity needs to be considered in light of their severe metabolic derangement. Indeed, the reduction in adiposity appears to be primarily a result of depressed lipogenesis, as markers of fat cell differentiation are still expressed in the fat pads of these animals.

\section{ADD1/SREBP1c}

Adipocyte determination and differentiation factor 1 (ADD1) is a member of the basic helix-loop-helix (bHLH) family of transcription factors. This family has been implicated in tissue-specific gene regulation, particularly in muscle, which shares a mesodermal origin with fat. ADD1 was isolated from a rat adipocyte cDNA expression library based on its ability to bind to an E-box motif (CANNTG), the DNA recognition site for bHLH proteins (Tontonoz et al. 1993). It is most highly expressed in brown fat, followed by liver, white fat, and kidney. This same transcription factor was independently purified and cloned based on its ability to bind to a sterol regulatory element, and named SREBP-1 (for sterol regulatory element binding protein-1) (Yokoyama et al. 1993). ADD1 corresponds at the amino terminus to the human SREBP-1c isoform, which predominates in animal tissues (Shimomura et al. 1997). The dual binding specificity of ADD1/SREBP1c to both E boxes and SREs is conferred by a critical tyrosine residue in the DNA binding region of the protein, which replaces the canoni$\mathrm{cal}$ arginine found in other bHLH family members (Kim et al. 1995). In liver cells, a mechanism has been described in which SREBPs embedded in the endoplasmic reticulum are cleaved in response to cholesterol depletion, and the amino-terminal fragments containing the DNA-binding domain are translocated to the nucleus (Brown and Goldstein 1997). It is currently unknown if this mechanism is recapitulated in the adipogenic and/ or lipogenic program in fat cells.

A role for ADD1/SREBP1c in adipogenesis was suggested by the observation that the expression of mRNA encoding this factor is induced dramatically as cultured preadipocytic cell lines are stimulated to undergo differentiation (Kim and Spiegelman 1996). In fact, the expression profile is similar to that for PPAR $\gamma$. Overexpression of ADD1/SREBP1c in 3T3-L1 cells in the presence of hormonal inducers of differentiation results in elevated adipocyte marker expression and lipid accumulation as compared to control cells. On the other hand, ectopic expression of ADD1/SREBP1c in undetermined fibroblasts results in some adipose conversion, but only under conditions strongly permissive for adipogenesis. Interestingly, expression of a dominant-negative ADD1/ 
SREBP1c (a non-DNA-binding mutant targeted to the nucleus) completely abolishes the ability of preadipocytes to undergo differentiation. These results suggest that, in vitro at least, ADD1/SREBP1c activity is required for adipogenesis, but unlike PPAR $\gamma$, is not strongly adipogenic on its own.

The mechanism by which ADD1/SREBP1c exercises its adipogenic function remains unknown, but several insights have been made that point to a relationship with PPAR $\gamma$. Coexpression of ADD1/SREBP1c with PPAR $\gamma$ in a PPAR $\gamma$ reporter system resulted in greater transcriptional activity, whereas ADD1/SREBP1c alone had little effect (Kim and Spiegelman 1996). One interpretation of this result is that ADD1/SREBP1c is responsible for generating some factor that enhances PPAR $\gamma$ activity. This notion was corroborated by the finding that the block in adipocyte differentiation mediated by dominant-negative ADD1/SREBP1c could be completely overcome by the addition of a TZD ligand for PPAR $\gamma$ (Kim et al. 1998b). Further support came from the observation that conditioned media from fibroblasts transfected with ADD1/SREBP1c contained a factor that could both bind to and activate a GAL4-PPAR $\gamma$ ligand binding domain fusion protein. Taken together, these results suggest that ADD1/SREBP1c is involved in the production of an endogenous PPAR $\gamma$ ligand. More recently, it has been proposed that PPAR $y$ itself is a direct target gene of ADD1/ SREBP1c (Fajas et al. 1999), providing alternative but not mutually exclusive mechanisms by which ADD1/ SREBP1c and PPAR $\gamma$ could cooperate to enhance adipogenesis.

Experiments in which ADD1/SREBP1c levels have been manipulated in the fat tissue of mice have been less clear in elucidating a role for this transcription factor in adipogenesis. Overexpression of a constitutively active ADD1/SREBP1c from the adipose-specific aP2 promoter would be expected to promote fat cell development, but instead resulted in the opposite phenotype: lipodystrophy (Shimomura et al. 1998). White fat depots in these mice were undersized, containing poorly differentiated adipocytes. Brown fat depots were enlarged, but more closely resembled white fat, with greater lipid accumulation. The mice were also diabetic and had fatty livers, phenotypes present in humans with lipodystrophy as well. Interestingly, this metabolic dysregulation was correctable with leptin infusion (Shimomura et al. 1999b). Clearly, lipodystrophy is an unexpected phenotype based on the in vivo cell culture results discussed above. However, the aP2 promoter generally produces very high transgene expression; indeed, aP2 accounts for several percent of total adipocyte protein. Furthermore, these experiments used a truncated, constitutively active form of ADD1/SREBP1c. Therefore the effects seen may have less to do with the normal program of differentiation but may reflect a dysregulated adipogenic program due to aberrantly high levels of ADD1/SREBP1c expression, perhaps causing non-specific promoter interactions. Effects on adipose tissue from a much lower level of ADD1/SREBP1c expression driven by the PEPCK promoter are apparently undetectable (Shimano et al. 1997a). On the other hand, in mice where both copies of the ADD1/SREBP1 gene have been disrupted, there is little effect on either the adipose tissue mass or gene expression, although most mice die in utero (Shimano et al. 1997b).

In contrast to the uncertainty concerning effects on adipogenesis, ADD1/SREBP1c clearly stimulates the expression of many of the genes necessary for lipogenesis in vivo. These genes include lipoprotein lipase, fatty acid synthase, and glycerol phosphate acyltransferase (Kim and Spiegelman 1996; Ericsson et al. 1997). The expression of ADD1/SREBP1c in fat is stimulated by refeeding after a fast, when lipogenesis is promoted (Kim et al. 1998a). This lipogenic response to feeding is blunted in ADD1/SREBP1c knockout mice (Shimano et al. 1999). The effect of refeeding is likely mediated by insulin, which strongly regulates ADD1/SREBP1c expression in fat and liver (Kim et al. 1998a; Foretz et al. 1999; Shimomura et al. 1999a).

\section{A transcriptional network}

Cumulative consideration of the experiments just described has led to a model for a transcriptional network in adipogenesis involving the sequential activation of C/EBPs and PPAR $\gamma$ (see Fig. 1). In this model, one major function of $\mathrm{C} / \mathrm{EBP} \beta$ and $\delta$ is to induce the expression of PPAR $\gamma$. As stated earlier, the endogenous expression of $\mathrm{C} / \mathrm{EBP} \beta$ and $\delta$ precedes that of PPAR $\gamma$, and ectopic expression of the former leads to induction of the latter (Wu et al. 1996). This induction is likely to be a direct transcriptional effect through C/EBP binding sites in the PPAR $\gamma$ promoter (Zhu et al. 1995; Fajas et al. 1997). $\operatorname{PPAR} \gamma$, in the current model, is then responsible for inducing $\mathrm{C} / \mathrm{EBP} \alpha$. Evidence for this arm of the cascade comes first from the temporal sequence of PPAR $\gamma$ and $\mathrm{C} / \mathrm{EBP} \alpha$ expression during adipogenesis, as well as from gain-of-function experiments in which ectopic expression of PPAR $\gamma$ or the application of specific PPAR $\gamma$ ligands induces $\mathrm{C} / \mathrm{EBP} \alpha \mathrm{mRNA}$. Genetic proof of this relationship was obtained from experiments in which cells (embryonic fibroblasts or embryonic stem cells) that are homozygous null for PPAR $\gamma$ were exposed to a prodifferentiative regimen. These cells do not become adipocytes and they express $\mathrm{C} / \mathrm{EBP} \alpha$ very poorly despite normal levels of C/EBP $\beta$ and $\delta$ (Kubota et al. 1999; Rosen et al. 1999). Interestingly, fibroblasts made from $\mathrm{C} / \mathrm{EBP}^{-/-}$ embryos have reduced levels of PPAR $\gamma$ and do not form fat readily when exposed to hormonal inducing agents in culture (Wu et al. 1999b). When C/EBP $\alpha$ is added back to these cells with a retroviral vector, the expression of PPAR $\gamma$ (and the ability to differentiate) is restored. This reveals a positive feedback loop within the cascade, in which there is mutually reinforcing expression of PPAR $\gamma$ and $\mathrm{C} / \mathrm{EBP} \alpha$; this feature ensures that, once initiated, the cascade will maintain the expression of these critical factors and, therefore, the terminally differentiated state.

There must be other important branches of this transcriptional network, however, to account for all of the available data. WAT and BAT of C/EBP $\beta$ and $\delta$ double 


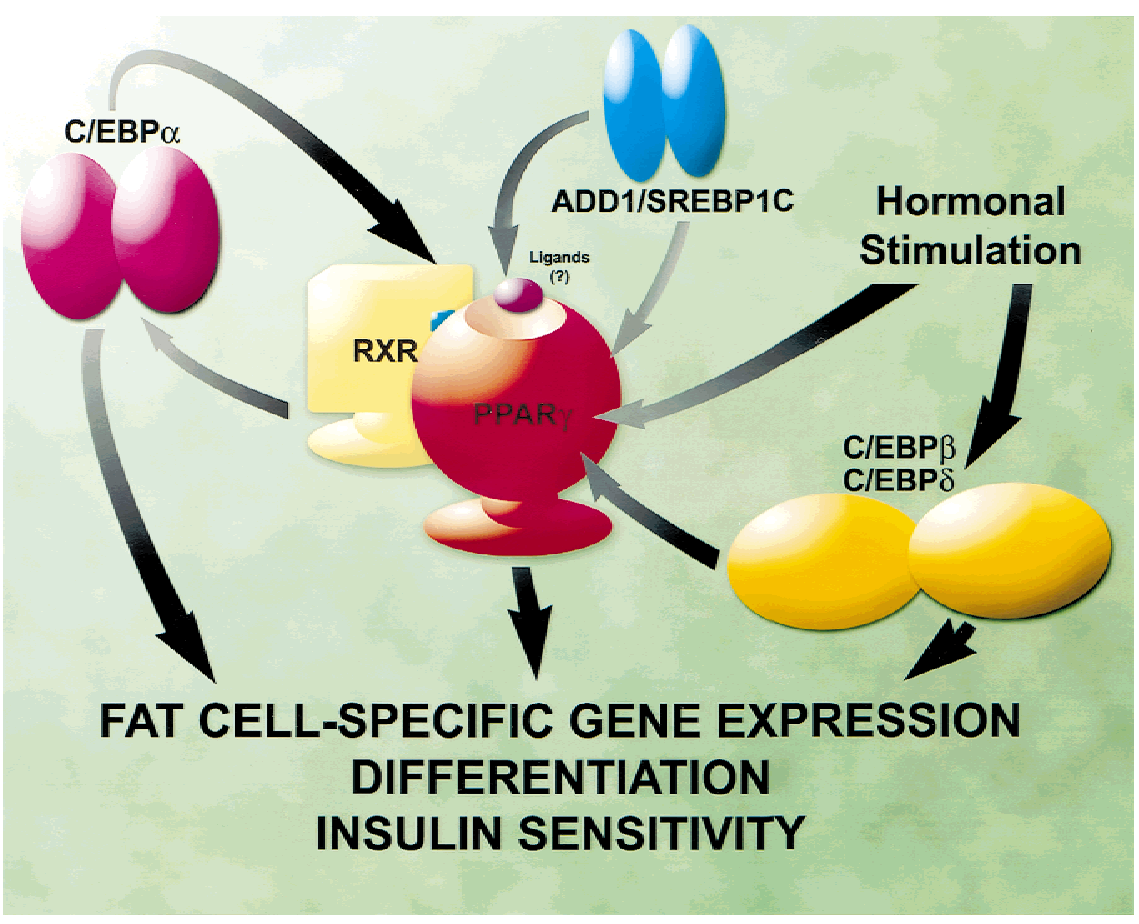

Figure 1. The transcriptional control of adipogenesis involves the activation of several families of transcription factors. These proteins are expressed in a network in which $\mathrm{C} / \mathrm{EBP} \beta$ and C/EBP $\delta$ are detected first, followed by $\operatorname{PPAR} \gamma$, which in turn activates $\mathrm{C} / \mathrm{EBP} \alpha . \mathrm{C} / \mathrm{EBP} \alpha$ exerts positive feedback on PPAR $\gamma$ to maintain the differentiated state. ADD1/SREBP1 can activate PPAR $\gamma$ by inducing its expression as well as by promoting the production of an endogenous PPAR $\gamma$ ligand. All of these factors contribute to the expression of genes that characterize the terminally differentiated phenotype. See text for further details. knockout mice express normal levels of PPAR $\gamma$ and $\mathrm{C} / \mathrm{EBP} \alpha$, implying that there must be a C/EBP $\beta$ - and $\delta$-independent mechanism for inducing PPAR $\gamma$ (Tanaka et al. 1997). As described earlier, this may involve ADD1/SREBP1c, which can induce PPAR $\gamma$ gene expression as well as PPAR $\gamma$ activation via the production of an endogenous ligand. Additionally, the clear defects in either lipid accumulation (in BAT, see above) or in fat cell hyperplasia (in WAT, see above) in these mice indicates that $\mathrm{C} / \mathrm{EBP} \beta$ and $\delta$ must play a role in other aspects of terminal adipocyte differentiation besides the mere induction of PPAR $\gamma$. This conclusion is consistent with data from liposarcoma cells that express a fusion protein that includes a dominant negative form of C/EBP called TLS-CHOP. These cells are deficient in adipogenesis despite a normal complement of PPAR $\gamma$ (Tontonoz et al. 1997).

There is also some uncertainty about whether the actions of C/EBPs and PPAR $\gamma$ represent parallel, reinforcing pathways of adipogenesis, or whether there is really one factor that drives adipogenesis, with the other factors serving primarily to "fine-tune" the process. It is already known that PPAR $\gamma$ can stimulate most, but not all, aspects of adipogenesis in $\mathrm{C} / \mathrm{EBP} \alpha$-deficient cells (Wu et al. 1999b). Fat cells lacking C/EBP $\alpha$ accumulate lipid and express most adipogenic markers, but they have poor insulin sensitivity. This is a result of diminished levels of insulin receptor and one of its primary substrates (IRS-1), as well as an uncharacterized postreceptor defect in insulin signaling. The converse experiments have not yet been performed but it will be interesting to know whether cells lacking PPAR $\gamma$ can be induced to differentiate into fat via expression of one or more of the C/EBP isoforms. Additionally, it is also clear that PPAR $\gamma$ and $\mathrm{C} / \mathrm{EBP} \alpha$ can act synergistically to activate differentiation-linked gene expression (El-Jack et al. 1999). The molecular basis for this synergy is not known, but it is worth noting that many fat cell genes have binding sites for both C/EBP proteins and PPAR $\gamma / R X R$, including PEPCK (Park et al. 1990; Tontonoz et al. 1995) and aP2 (Christy et al. 1989; Tontonoz et al. 1994b), perhaps suggesting an interaction with a common transcriptional mediator. Another possibility to explain this synergy would be the involvement of C/EBP proteins in inducing the expression of enzymes that produce PPAR $\gamma$ ligands, although there is no direct evidence for this scenario.

Although no transcription factors have been identified that are expressed specifically in brown fat cells, PPAR $\gamma$ and $\mathrm{C} / \mathrm{EBP} \alpha$ are induced during brown adipogenesis in a similar fashion to white cell differentiation. As already mentioned, brown fat development was retarded in a PPAR $\gamma$ knockout mouse that was generated through tetraploid rescue of placental insufficiency (Barak et al. 1999). In addition, activation of PPAR $\gamma$ by TZD ligands in brown adipocyte cell lines such as HIB1 and HB2 results in robust differentiation, and the administration of TZDs to rodents induces the accumulation of interscapular BAT (Tai et al. 1996). A role for C/EBP proteins in BAT adipogenesis is also evident, as mice lacking $\mathrm{C} / \mathrm{EBP} \alpha$ or both $\mathrm{C} / \mathrm{EBP} \beta$ and $\delta$ have reduced lipid accumulation in this cell type and decreased UCP-1 (Wang et al. 1995; Tanaka et al. 1997). PPAR $\alpha$ is also expressed at relatively high levels in BAT, although there are no data to support a role in lineage development for this protein. $\operatorname{PPAR} \alpha$ is known to be important for the $\beta$-oxidation of fatty acids in tissues other than BAT (Dreyer et al. 1992), and as this process is very important in brown fat, it is likely that PPAR $\alpha$ plays this role here as well. 


\section{Other transcription factors}

There have been reports of several other transcription factors that are temporally and/or functionally linked to adipogenesis. Although none of these have been shown to affect fat cell development as profoundly as PPAR $\gamma$ and the C/EBPs, it is quite possible that some of these will be found to act as important modulators of certain aspects of fat cell development and function.

PPAR $\delta$ is expressed rather ubiquitously in vivo (Braissant et al. 1996). Some reports suggest that PPAR $\delta$ can promote adipogenesis when expressed ectopically in certain fibroblastic cells (Amri et al. 1995). However, these studies utilized only nonselective PPAR activators, so that activation of PPAR $\gamma$ confounds the interpretation of these experiments. In other studies, activating ectopically expressed PPAR $\delta$ with a variety of ligands did not promote adipogenesis. One study made use of a PPAR $\delta$ selective agonist in 3T3-L1 cells, which express endogenous PPAR $\delta$, and found no induction of fat cell formation (Berger et al. 1999). Although the precise biological function of PPAR $\delta$ remains to be determined, a major role in adipogenesis seems very unlikely.

Other transcription factors regulated during adipogenesis include the orphan nuclear receptors ROR $\gamma$ (Austin et al. 1998) and ERR $\alpha$ (Sladek et al. 1997), as well as various STAT proteins (Stephens et al. 1999; Stewart et al. 1999). NFAT (nuclear factor of activated T cells) is present in cultured adipocytes and can bind and activate the aP2 promoter (Ho et al. 1998). Certain high-mobilitygroup (HMG) proteins, which are important in chromatin modeling and transcriptional regulation, have also been shown to be components of fusion proteins that cause benign tumors of fat tissue called lipomas (Ashar et al. 1995), and mice nullizygous for certain HMGI isoforms are resistant to obesity (Anand and Chada 2000). Finally, the cyclic AMP response element binding protein (CREB) has been shown recently to be both necessary and sufficient for adipogenesis in vitro (Reusch et al. 2000). This may partially explain the requirement for cAMP in the prodifferentiative cocktail used to promote adipogenesis in 3T3-L1 cells. The functional significance of most of these proteins in inducing or maintaining the terminally differentiated phenotype in vivo has not yet been extensively explored.

\section{Coactivators of transcriptional regulation by PPAR $\gamma$ and $\mathrm{C} / \mathrm{EBPs}$}

In order for transcription factors to activate gene expression, they must open up tightly wound chromatin structures and recruit elements of the basal transcription apparatus. This set of activities is executed by a group of proteins called coactivators, the study of which has simply exploded in the last five years (Freedman 1999; Glass and Rosenfeld 2000). The interaction of multiple coactivators with transcription factors in different temporal and spatial contexts provides another possible level of regulation to gene expression. Nuclear hormone receptors such as PPAR $\gamma$, for example, can interact with co- activators like the p160 family, CBP/p300, and others. These proteins bind to the carboxy-terminal transcriptional activation function-2 (AF-2) domain of nuclear hormone receptors in the presence of ligand binding. The sites within coactivators that mediate this binding are usually characterized by a hydrophobic stretch of amino acids containing an LXXLL motif. Although no one transcriptional coactivator has been shown to be absolutely specific for any member of the nuclear receptor family, functional specificity could be achieved by cell-type selective expression or by regulation of receptor-coactivator interactions by diverse signaling pathways.

Two dominant classes of coactivator complex have been reported to be recruited to nuclear hormone receptors: the p160/CBP/p300 complex and the DRIP/TRAP complex. The first type is represented by SRC-1/NCoA1, TIF2/GRIP1/NCoA2, and pCIP/ACTR/AIB1 (Leo and Chen 2000). In addition to binding the AF-2 domain of PPAR $\gamma$, these proteins also interact with CBP/p300 (Yao et al. 1996). CBP/p300 can also interact directly with $\operatorname{PPAR} \gamma$, thus providing potential stability to the complex through multiple contact points (Gelman et al. 1999). The p160 proteins and CBP/p300 both possess intrinsic histone acetyltransferase (HAT) activity, which is necessary to open the chromatin structure to allow full activation of transcription. Despite a wealth of experiments demonstrating a requirement for coactivator binding for maximal PPAR $\gamma$ activity in vitro, data linking these coactivators to adipogenesis in vivo have so far proved difficult to come by. Mice lacking SRC-1, for example, have apparently normal fat development, suggesting functional redundancy within the p160 family (Xu et al. 1998). Mice lacking CBP or p300 die in utero before the appearance of fat (Yao et al. 1998). Other strategies will be required to determine the specific role in fat development for coactivators such as CBP/p300 whose presence is necessary for embryonic viability, such as tissue-specific tissue knockouts or chimeric analysis.

The second class of coactivators that interact with nuclear receptors in a ligand dependent manner is the DRIP/TRAP/ARC complex (Fondell et al. 1996; Naar et al. 1999; Rachez et al. 1999). One of the critical components of this complex for transcriptional activation is DRIP205/TRAP220. Interestingly, DRIP205/TRAP220 shares identity with PBP (PPAR $\gamma$ binding protein), cloned using a yeast two-hybrid screen with PPAR $\gamma$ as bait (Zhu et al. 1997). Interestingly, the PBP null mutation is embryonic lethal because of defects in placental development that are reminiscent of the pathology seen in PPAR y null embryos (Zhu et al. 2000). However, since PPAR $\gamma$ transcriptional activity is only modestly affected in cells lacking PBP, the requirement for this factor in PPAR $\gamma$-mediated adipogenesis remains to be determined.

Two coactivators of PPAR $\gamma$ that are not ligand dependent, but which show considerable biological selectivity, are PPAR $\gamma$ coactivator-1 and -2 (PGC-1,-2). PGC-1 was cloned from brown fat in a yeast two-hybrid screen using PPAR $\gamma$ as a bait (Puigserver et al. 1998b). PGC-1 is devoid of homology to other known coactivators, except 
for a typical LXXLL domain. Interestingly, the carboxyl terminus of this protein contains motifs linked previously to RNA processing, suggesting that PGC-1 could provide a link between transcriptional activation and splicing. Although it does not appear that PGC-1 has endogenous HAT activity, it does interact through its amino terminus with $\mathrm{p} 160 / \mathrm{CBP} / \mathrm{p} 300$, proteins that do possess such activity (Puigserver et al. 1999). One of the most interesting aspects of PGC-1 is its tissue distribution, in that it is expressed in brown but not white fat. Its expression can be induced dramatically in brown fat and skeletal muscle in response to cold exposure or changes in nutritional status, and when expressed ectopically in white fat cells in vitro, PGC-1 induces genes that are associated with the brown fat phenotype, including UCP-1 and components of the electron transport chain. It also induces mitochondrial biogenesis, likely through the coactivation of a non-nuclear hormone receptor transcription factor, nuclear respiratory factor-1 (NRF-1) (Wu et al. 1999a). Studies on transgenic mice expressing PGC-1 in white fat and mice with targeted PGC-1 deletions are currently ongoing.

Domain swap experiments between PPAR $\gamma$ and PPAR $\delta$ show that a significant fraction of the adipogenic action of PPAR $\gamma$ resides in the amino-terminal AF-1 domain (Brun et al. 1996). Using this amino-terminal region as bait in a two-hybrid screen utilizing a white fat library led to the discovery of PGC-2 (Castillo et al. 1999). PGC-2 is a small $26-\mathrm{kD}$ protein that does not share homology with PGC-1 or other coactivators. Ectopic expression of PGC-2 in preadipocytes, however, causes a dramatic increase in fat cell differentiation at both the morphological and molecular levels. PGC-2 itself does not have domains suggestive of intrinsic HAT activity; this may suggest that it can help recruit other HAT-containing coactivators to PPAR $y$ in a manner analagous to PGC- 1 .

Little is known about coactivator complexes interacting with C/EBP family members. Two types of coactivators have been reported to interact with C/EBP $\beta$. One is the chromatin remodeling SWI/SNF complex that is recruited in myeloid cells to activate certain target genes (Kowenz-Leutz and Leutz 1999). The second type is the $\mathrm{CBP} / \mathrm{p} 300$ coactivator (Mink et al. 1997). Because it is also a potent activator of $\operatorname{PPAR} \gamma$, it is possible that CBP/ p300 is important in the synergistic effects seen between $\mathrm{C} / \mathrm{EBP}$ proteins and PPAR $\gamma$.

\section{Unresolved issues and future prospects}

Years of intensive study have definitively identified several key molecules that regulate the process of adipogenesis, and a reasonable working model of the network of interactions between these factors is in place. Despite these advances, it is likely that the cast of characters involved in inducing and maintaining the differentiated fat cell phenotype will grow, and further levels of regulation will be uncovered.

There are important questions surrounding, for example, the differentiation of white vs. brown fat. It is currently unknown whether BAT and WAT derive from the same preadipocytic precursors or whether they arise independently from undetermined mesenchymal stem cells that also retain myogenic and/or chondrogenic potential. Available data do not address this issue, although the former model seems most likely given the similarity in the transcriptional cascade that is operational both in BAT and WAT (Fig. 2). Additionally, observations indicating that UCP-1 content can be increased by stimulation with $\beta$-adrenergic agonists (Bouillaud et al. 1984) raise the issue of whether BAT can be formed by transdifferentiation of mature WAT. This question awaits studies utilizing the conditional expression of potential BAT-promoting factors, such as PGC-1, in mature white fat.

Other important questions center on the identification of transcription factors that regulate the development of early mesenchymal precursors, prior to determination to the adipocytic lineage. Very little is known about these pathways presently, although the introduction of transcriptional profiling microarrays and stem cell technology promises to provide insights in this area.

Finally, there is an enormous body of literature describing extracellular factors and intracellular signal transduction pathways that influence the adipogenic potential of cells in vitro and in vivo. These include the identification of hormones that induce adipogenesis, such as insulin-like growth factor-1 (IGF-1), insulin, growth hormone, glucocorticoids, and thyroid hormone, as well as intracellular pathways involving cAMP and p38 MAP kinase (Mandrup and Lane 1997; Engelman et al. 1998, 1999; Gregoire et al. 1998). There is an equally impressive body of studies that identify agents that inhibit fat cell formation, including cytokines such as IL-1 and TNF- $\alpha$, cell surface proteins such as the preadipocyte-specific protein Pref-1, and intracellular pathways involving MAP kinases such as Erk1, Erk2, and JNK (Gregoire et al. 1998). The link between these varied factors and the transcriptional components that regulate adipogenesis remains tenuous at best, although some relationships have become more clear recently. For example, the well-documented inhibition of adipogenesis by MAP kinases can be at least partially explained by the phosphorylation of specific residues of PPAR $\gamma(\mathrm{Hu}$ et al. 1996; Adams et al. 1997b; Camp and Tafuri 1997; Font de Mora et al. 1997; Camp et al. 1999) and RXR (Solomon et al. 1999), which inhibits their activity. Further investigation will be necessary to unite the myriad observations on hormonal influences on adipogenesis with signal transduction pathways and ultimately with changes in transcriptional activity.

Despite these and other uncertainties, it has become possible to contemplate manipulating the process of adipogenesis in vivo. One could imagine reducing adipose cell mass with, for example, a PPAR $\gamma$ antagonist or antisense oligonucleotides to one or several C/EBP isoforms. Assuming this is possible, it remains to be ascertained whether this would yield medical benefits. Since obesity represents an excessive accumulation of adipose tissue, a genetic or pharmacological reduction in adipose 


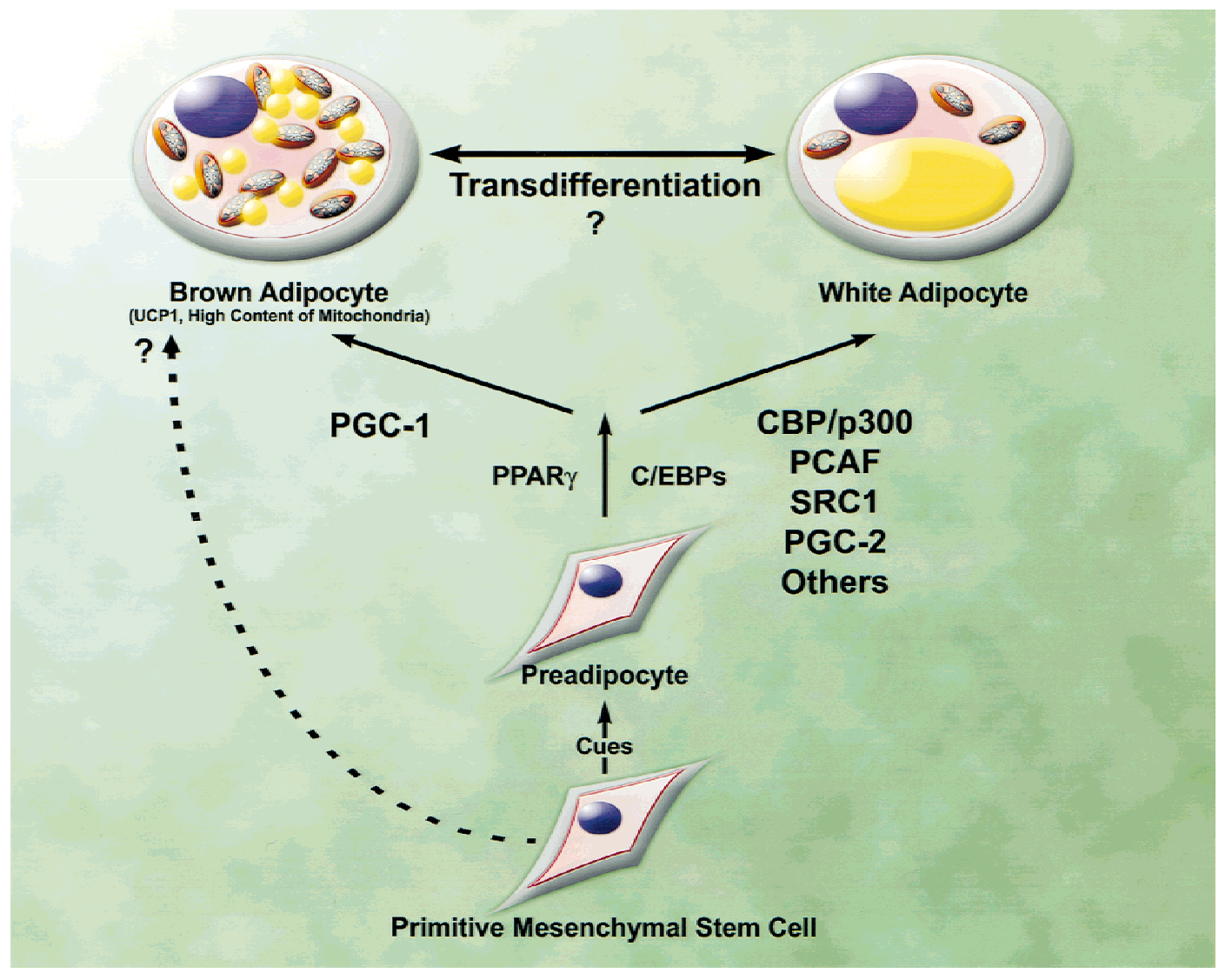

Figure 2. White and brown adipocytes derive from fibroblastic precursor cells via the concerted action of extracellular signals and intrinsic transcription factors and coactivators. Questions surround several issues in brown fat development, including the identity of specific factors that promote brown fat adipogenesis, and whether brown fat and white fat share common precursor cells or derive separately from stem cells via brown- and white-specific preadipocytes (broken line). It is also unclear if brown and white fat cells can be transdifferentiated to one another. See text for further details.

cells might seem an attractive approach to this disorder. However, it must be remembered that obesity is fundamentally a disorder of energy balance, where energy intake exceeds energy expenditure. Any attempt to manipulate adipogenesis without addressing the dysregulated energy balance of the organism would simply require that excess calories be deposited elsewhere, with potentially deleterious effects. In fact, this is exactly what is seen in transgenic mice that do not make fat, such as the ADD1/SREBP1c overexpression model described earlier (Shimomura et al. 1998). This has also been seen in mice expressing a dominant negative C/EBP allele (Moitra et al. 1998). The consequences of this forced leanness are hepatomegaly (because the liver takes up and stores fatty acids if circulating levels become elevated), hyperlipidemia, and diabetes; this mimics the situation in human lipoatrophic diabetes. Hence, there is no evidence to date that direct reduction of adipogenesis has any beneficial effects. In fact, it has already been pointed out that TZDs, which are synthetic activators of PPAR $\gamma$ and potent stimulators of adipogenesis, are used clinically to reduce hyperglycemia in type 2 diabetic patients. On the other hand, it is possible that increasing brown fat adipogenesis could be metabolically useful. Pharmacologic strategies to increase the amount or activity of PGC-1 could be useful, if this can be done without deleterious effects. Of course, the likelihood of success depends upon a better understanding of the function of PGC-1 in non-thermogenic tissues such as the heart and brain.

The next few years bring the promise of more complete knowledge of the basic processes underpinning the differentiation of adipocytes and development in general. This promise continues to fuel excitement in this area of research, and bouys the hope that future discoveries may one day yield therapeutic benefits.

\section{Acknowledgments}

We thank members of the Spiegelman lab for helpful discussions, and Eric Smith for preparing the figures. E.D.R is supported by KO8 Award DK02535. C.J.W is supported by the Medical Research Council of Canada and the Alberta Heritage Foundation for Medical Research. P.P. is the recipient of a postdoctoral fellowhip from the Juvenile Diabetes Foundation. B.M.S. is supported by National Institutes of Health grants DK54477 and R37DK31405. 


\section{References}

Adams, M., C.T. Montague, J.B. Prins, J.C. Holder, S.A. Smith, L. Sanders, J.E. Digby, C.P. Sewter, M.A. Lazar, K.K. Chatterjee et al. 1997a. Activators of peroxisome proliferator-activated receptor $\gamma$ have depot-specific effects on human preadipocyte differentiation. J. Clin. Invest. 100: 3149-3153.

Adams, M., M.J. Reginato, D. Shao, M.A. Lazar, and V.K. Chatterjee. 1997b. Transcriptional activation by peroxisome proliferator-activated receptor $\gamma$ is inhibited by phosphorylation at a consensus mitogen-activated protein kinase site. J. Biol. Chem. 272: 5128-5132.

Altiok, S., M. Xu, and B.M. Spiegelman. 1997. PPAR $\gamma$ induces cell cycle withdrawal: Inhibition of E2F/DP DNA-binding activity via down-regulation of PP2A. Genes \& Dev. 11: 1987-1998.

Amri, E.Z., F. Bonino, G. Ailhaud, N.A. Abumrad, and P.A. Grimaldi. 1995. Cloning of a protein that mediates transcriptional effects of fatty acids in preadipocytes. Homology to peroxisome proliferator-activated receptors. J. Biol. Chem. 270: $2367-2371$.

Anand, A. and K. Chada. 2000. In vivo modulation of HMGIc reduces obesity. Nat. Genet. 24: 377-380.

Ashar, H.R., M.S. Fejzo, A. Tkachenko, X. Zhou, J.A. Fletcher, S. Weremowicz, C.C. Morton, and K. Chada. 1995. Disruption of the architectural factor HMGI-C: DNA-binding AT hook motifs fused in lipomas to distinct transcriptional regulatory domains. Cell 82: 57-65.

Austin, S., A. Medvedev, Z.H. Yan, H. Adachi, T. Hirose, and A.M. Jetten. 1998. Induction of the nuclear orphan receptor RORgamma during adipocyte differentiation of D1 and 3T3L1 cells. Cell Growth Diff. 9: 267-276.

Bachmeier, M. and G. Loffler. 1997. The effect of platelet-derived growth factor and adipogenic hormones on the expression of CCAAT/enhancer-binding proteins in 3T3-L1 cells in serum-free conditions. Eur. J. Biochem. 243: 128-133.

Barak, Y., M.C. Nelson, E.S. Ong, Y.Z. Jones, P. Ruiz-Lozano, K.R. Chien, A. Koder, and R.M. Evans. 1999. PPAR gamma is required for placental, cardiac, and adipose tissue development. Mol. Cell 4: 585-595.

Barroso, I., M. Gurnell, V.E. Crowley, M. Agostini, J.W. Schwabe, M.A. Soos, G.L. Maslen, T.D. Williams, H. Lewis, A.J. Schafer, V.K. Chatterjee, and S. O'Rahilly. 1999. Dominant negative mutations in human PPARgamma associated with severe insulin resistance, diabetes mellitus and hypertension. Nature 402: 880-883.

Black, A.R. and J. Azizkhan-Clifford. 1999. Regulation of E2F: A family of transcription factors involved in proliferation control. Gene 237: 281-302.

Berger, J., M.D. Leibowitz, T.W. Doebber, A. Elbrecht, B. Zhang, G. Zhou, C. Biswas, C.A. Cullinan, N.S. Hayes, Y. Li et al. 1999. Novel peroxisome proliferator-activated receptor (PPAR) gamma and PPAR delta ligands produce distinct biological effects. J. Biol. Chem. 274: 6718-6725.

Bouillaud, F., D. Ricquier, G. Mory, and J. Thibault. 1984. Increased level of mRNA for the uncoupling protein in brown adipose tissue of rats during thermogenesis induced by cold exposure or norepinephrine infusion. J. Biol. Chem. 259: 11583-11586.

Braissant, O., F. Foufelle, C. Scotto, M. Dauça, and W. Wahli. 1996. Differential expression of peroxisome proliferator-activated receptors (PPARs): Tissue distribution of PPAR- $\alpha,-\beta$, and $-\gamma$ in the adult rat. Endocrinol. 137: 354-366.

Brown, M.S. and J.L. Goldstein. 1997. The SREBP pathway: Regulation of cholesterol metabolism by proteolysis of a membrane-bound transcription factor. Cell 89: 331-340.
Brun, R.P., P. Tontonoz, B.M. Forman, R. Ellis, J. Chen, R.M. Evans, and B.M. Spiegelman. 1996. Differential activation of adipogenesis by multiple PPAR isoforms. Genes \& Dev. 10: 974-984.

Camp, H.S. and S.R. Tafuri. 1997. Regulation of peroxisome proliferator-activated receptor $\gamma$ activity by mitogen-activated protein kinase. J. Biol. Chem. 272: 10811-10816.

Camp, H.S., S.R. Tafuri, and T. Leff. 1999. c-Jun N-terminal kinase phosphorylates peroxisome proliferator-activated receptor- $\gamma 1$ and negatively regulates its transcriptional activity. Endocrinol. 140: 392-397.

Cao, Z., R.M. Umek, and S.L. McKnight. 1991. Regulated expression of three C/EBP isoforms during adipose conversion of 3T3-L1 cells. Genes \& Dev. 5: 1538-1552.

Castillo, G., R.P. Brun, J.K. Rosenfield, S. Hauser, C.W. Park, A.E. Troy, M.E. Wright, and B.M. Spiegelman. 1999. An adipogenic cofactor bound by the differentiation domain of PPARgamma. EMBO J. 18: 3676-3687.

Castrillo, A., M.J. Diaz-Guerra, S. Hortelano, P. Martin-Sanz, and L. Bosca. 2000. Inhibition of IkappaB kinase and IkappaB phosphorylation by 15-deoxy-Delta(12,14)-prostaglandin J(2) in activated murine macrophages. Mol. Cell. Biol. 20: 1692-1698.

Chapman, A.B., D.M. Knight, B.S. Dieckmann, and G.M. Ringold. 1984. Analysis of gene expression during differentiation of adipogenic cells in culture and hormonal control of the developmental program. J. Biol. Chem. 259: 1554815555.

Chen, P.L., D.J. Riley, Y. Chen, and W.H. Lee. 1996. Retinoblastoma protein positively regulates terminal adipocyte differentiation through direct interaction with C/EBPs. Genes \& Dev. 10: 2794-2804.

Christy, R.J., V.W. Yang, J.M. Ntambi, D.E. Getman, W.H. Landschulz, A.D. Friedman, Y. Nakabeppu, J.T. Kelly, and M.D. Lane. 1989. Differentiation-induced gene expression in 3T3-L1 preadipocyte: CCAAT/enhancer-binding protein interacts with and activates the promoters of two adipocytespecific genes. Genes \& Dev. 3: 1323-1335.

Darlington, G.J., S.E. Ross, and O.A. MacDougald. 1998. The role of C/EBP genes in adipocyte differentiation. I. Biol. Chem. 273: 30057-30060.

Devine, J.H., D.W. Eubank, D.E. Clouthier, P. Tontonoz, B.M. Spiegelman, R.E. Hammer, and E.G. Beale. 1999. Adipose expression of the phosphoenolpyruvate carboxykinase promoter requires peroxisome proliferator-activated receptor gamma and 9-cis- retinoic acid receptor binding to an adipocyte-specific enhancer in vivo. J. Biol. Chem. 274: 1360413612.

Djian, P., D.A.K. Roncari, and C.H. Hollenberg. 1985. Adipocyte precursor clones vary in capacity for differentiation. Metabolism 34: 880-883.

Dreyer, C., G. Krey, H. Keller, F. Givel, G. Helftenbein, and W. Wahli. 1992. Control of the peroxisomal beta-oxidation pathway by a novel family of nuclear hormone receptors. Cell 68: 879-887.

El-Jack, A.K., J.K. Hamm, P.F. Pilch, and S.R. Farmer. 1999. Reconstitution of insulin-sensitive glucose transport in fibroblasts requires expression of both PPAR gamma and C/EBP alpha. I. Biol. Chem. 274: 7946-7951.

Engelman, J.A., M.P. Lisanti, and P.E. Scherer. 1998. Specific inhibitors of p38 mitogen-activated protein kinase block 3T3- L1 adipogenesis. J. Biol. Chem. 273: 32111-32120.

Engelman, J.A., A.H. Berg, R.Y. Lewis, A. Lin, M.P. Lisanti, and P.E. Scherer. 1999. Constitutively active mitogen-activated protein kinase kinase 6 (MKK6) or salicylate induces spontaneous 3T3-L1 adipogenesis. J. Biol. Chem. 274: 3563035638. 
Entenmann, G. and H. Hauner. 1996. Relationship between replication and differentiation in cultured human adipocyte precursor cells. Am. J. Physiol. 270: C1011-C1016.

Ericsson, J., S.M. Jackson, J.B. Kim, B.M. Spiegelman, and P.A. Edwards. 1997. Identification of glycerol-3-phosphate acyltransferase as an adipocyte determination and differentiation factor 1- and sterol regulatory element-binding proteinresponsive gene. J. Biol. Chem. 272: 7298-7305.

Fajas, L., D. Auboeuf, E. Raspé, K. Schoonjans, A.-M. Lefebvre, R. Saladin, J. Najib, M. Laville, J.-C. Fruchart, S. Deeb, A. Vidal-Puig, J. Flier, M.R. Briggs, B. Staels, H. Vidal, and J. Auwerx. 1997. The organization, promoter analysis, and expression of the human PPAR $\gamma$ gene. J. Biol. Chem. 272: 18779-18789.

Fajas, L., K. Schoonjans, L. Gelman, J.B. Kim, J. Najib, G. Martin, J.-C. Fruchart, M. Briggs, B.M. Spiegelman, and J. Auwerx. 1999. Regulation of peroxisome proliferator-activated receptor $\gamma$ expression by adipocyte differentiation and determination factor 1 /sterol regulatory element binding protein 1: Implications for adipocyte differentiation and metabolism. Mol. Cell. Biol. 19: 5495-5503.

Flodby, P., C. Barlow, H. Kylefjord, L. Ahrlund-Richter, and K.G. Xanthopoulos. 1996. Increased hepatic cell proliferation and lung abnormalities in mice deficient in CCAAT/ enhancer binding protein alpha. J. Biol. Chem. 271: 2475324760.

Fondell, J.D., H. Ge, and R.G. Roeder. 1996. Ligand induction of a transcriptionally active thyroid hormone receptor coactivator complex. Proc. Natl. Acad. Sci. 93: 8329-8333.

Font de Mora, J., A. Porras, N. Ahn, and E. Santos. 1997. Mitogen-activated protein kinase activation is not necessary for, but antagonizes, 3T3-L1 adipocyte differentiation. Mol. Cell. Biol. 17: 6068-6075.

Foretz, M., C. Pacot, I. Dugail, P. Lemarchand, C. Guichard, X. Le Liepvre, C. Berthelier-Lubrano, B. Spiegelman, J.B. Kim, P. Ferre, and F. Foufelle. 1999. ADD1/SREBP-1c is required in the activation of hepatic lipogenic gene expression by glucose. Mol. Cell. Biol. 19: 3760-3768.

Forman, B.M., P. Tontonoz, J. Chen, R.P. Brun, B.M. Spiegelman, and R.M. Evans. 1995. 15-Deoxy- $\Delta^{12,14}$-prostaglandin $\mathrm{J}_{2}$ is a ligand for the adipocyte determination factor PPAR $\gamma$. Cell 83: 803-812.

Forman, B.M., J. Chen, and R.M. Evans. 1997. Hypolipidemic drugs, polyunsaturated fatty acids, and eicosanoids are ligands for peroxisome proliferator-activated eaceptors $\alpha$ and б. Proc. Natl. Acad. Sci. 94: 4312-4317.

Freedman, L.P. 1999. Increasing the complexity of coactivation in nuclear receptor signaling. Cell 97: 5-8.

Freytag, S.O., D.L. Paielli, and J.D. Gilbert. 1994. Ectopic expression of the CCAAT/enhancer binding protein alpha promotes the adipogenic program in a variety of mouse fibroblastic cells. Genes \& Dev. 8: 1654-1663.

Garlid, K.D., M. Jaburek, and P. Jezek. 1998. The mechanism of proton transport mediated by mitochondrial uncoupling proteins. FEBS Lett. 438: 10-14.

Gelman, L., G. Zhou, L. Fajas, E. Raspe, J.C. Fruchart, and J. Auwerx. 1999. p300 interacts with the N- and C-terminal part of PPARgamma2 in a ligand-independent and -dependent manner, respectively. J. Biol. Chem. 274: 7681-7688.

Glass, C.K. and M.G. Rosenfeld. 2000. The coregulator exchange in transcriptional functions of nuclear receptors. Genes \& Dev. 14: 121-141.

Graves, R.A., P. Tontonoz, and B.M. Spiegelman. 1992. Analysis of a tissue-specific enhancer: ARF6 regulates adipogenic gene expression. Mol. Cell. Biol. 12: 1202-1208.

Green, H. and O. Kehinde. 1974. Sublines of mouse 3T3 cells that accumulate lipid. Cell 1: 113-116.

1975. An established cell line and its differentiation in culture II. Factors affecting adipose conversion. Cell 5: 19_ 27.

1976. Spontaneous heritable changes leading to increased adipose conversion in 3T3 cells. Cell 7: 105-113.

Gregoire, F.M., C.M. Smas, and H.S. Sul. 1998. Understanding adipocyte differentiation. Physiolog. Rev. 78: 783-809.

Gurnell, M., J.M. Wentworth, M. Agostini, M. Adams, T.N. Collingwood, C. Provenzano, P.O. Browne, O. Rajanayagam, T.P. Burris, J.W. Schwabe, M.A. Lazar, and V.K. Chatterjee. 2000. A dominant-negative peroxisome proliferator-activated receptor gamma (PPARgamma) mutant is a constitutive repressor and inhibits PPARgamma-mediated adipogenesis. J. Biol. Chem. 275: 5754-5759.

Hansen, J.B., R.K. Peterson, B.M. Larsen, J. Bartkova, J. Alsner, and K. Kristiansen. 1999. Activation of peroxisome proliferator-activated receptor $\gamma$ bypasses the function of the retinoblastoma protein in adipocyte differentiation. J. Biol. Chem. 274: 2386-2393.

Higgins, C., S. Chatterjee, and V. Cherington. 1996. The block of adipocyte differentiation by a C-terminally truncated, but not by full-length, simian virus 40 large tumor antigen is dependent on an intact retinoblastoma susceptibility protein family binding domain. J. Virol. 70: 745-752.

Ho, I.C., J.H. Kim, J.W. Rooney, B.M. Spiegelman, and L.H. Glimcher. 1998. A potential role for the nuclear factor of activated $\mathrm{T}$ cells family of transcriptional regulatory proteins in adipogenesis. Proc. Natl. Acad. Sci. 95: 1553715541.

Hu, E., P. Tontonoz, and B.M. Spiegelman. 1995. Transdifferentiation of myoblasts by the adipogenic transcription factors PPAR $\gamma$ and C/EBP $\alpha$. Proc. Natl. Acad. Sci. 92: 9856-9860.

Hu, E., J.B. Kim, P. Sarraf, and B.M. Spiegelman. 1996. Inhibition of adipogenesis through MAP kinase-mediated phosphorylation of PPAR $\gamma$. Science 274: 2100-2103.

Kaelin, W.G., Jr. 1999. Functions of the retinoblastoma protein. BioEssays 21: 950-958.

Kim, J.B. and B.M. Spiegelman. 1996. ADD1/SREBP1 promotes adipocyte differentiation and gene expression linked to fatty acid metabolism. Genes \& Dev. 10: 1096-1107.

Kim, J.B., G.D. Spotts, Y.D. Halvorsen, H.M. Shih, T. Ellenberger, H.C. Towle, and B.M. Spiegelman. 1995. Dual DNA binding specificity of ADD1/SREBP1 controlled by a single amino acid in the basic helix-loop-helix domain. Mol. Cell. Biol. 15: 2582-2588.

Kim, J.B., P. Sarraf, M. Wright, K.M. Yao, E. Mueller, G. Solanes, B.B. Lowell, and B.M. Spiegelman. 1998a. Nutritional and insulin regulation of fatty acid synthetase and leptin gene expression through ADD1/SREBP1. J. Clin. Invest. 101: 1-9.

Kim, J.B., H.M. Wright, M. Wright, and B.M. Spiegelman. 1998b. ADD1/SREBP1 activates PPAR $\gamma$ through the production of endogenous ligand. Proc. Natl. Acad. Sci. 95: 4333-4337.

Kletzien, R.F., S.D. Clarke, and R.G. Ulrich. 1992. Enhancement of adipocyte differentiation by an insulin-sensitizing agent. Mol. Pharmacol. 41:393-398.

Kliewer, S.A., B.M. Forman, B. Blumberg, E.S. Ong, U. Borgmeyer, D.J. Mangelsdorf, K. Umesono, and R.M. Evans. 1994. Differential expression and activation of a family of murine peroxisome proliferator-activated receptors. Proc. Natl. Acad. Sci. 91: 7355-7359.

Kliewer, S.A., J.M. Lenhard, T.M. Willson, I. Patel, D.C. Morris, and J.M. Lehmann. 1995. A prostaglandin $\mathrm{J}_{2}$ metabolite binds peroxisome proliferator-activated receptor $\gamma$ and promotes adipocyte differentiation. Cell 83: 813-819.

Kliewer, S.A., S.S. Sundseth, S.A. Jones, P.J. Brown, G.B. Wisely, 
C.S. Koble, P. Devchand, W. Wahli, T.M. Willson, J.M. Lenhard, and J.M. Lehmann. 1997. Fatty acids and eicosanoids regulate gene expression through direct interactions with peroxisome proliferator-activated receptors $\alpha$ and $\gamma$. Proc. Nat1. Acad. Sci. 94: 4318-4323.

Kowenz-Leutz, E. and A. Leutz. 1999. A C/EBP beta isoform recruits the SWI/SNF complex to activate myeloid genes. Mol. Cell 4: 735-743.

Kubota, N., Y. Terauchi, H. Miki, H. Tamemoto, T. Yamauchi, K. Komeda, S. Satoh, R. Nakano, C. Ishii, T. Sugiyama et al. 1999. PPAR gamma mediates high-fat diet-induced adipocyte hypertrophy and insulin resistance. Mol. Cell 4: 597609.

Lefebvre, A.-M., M. Laville, N. Vega, J.P. Riou, L. van Gaal, J. Auwerx, and H. Vidal. 1998. Depot-specific differences in adipose tissue gene expression in lean and obese subjects. Diabetes 47: 98-103.

Lehmann, J.M., L.B. Moore, T.A. Smith-Oliver, W.O. Wilkison, T.M. Willson, and S.A. Kliewer. 1995. An antidiabetic thiazolidinedione is a high affinity ligand for peroxisome proliferator-activated receptor $\gamma$ (PPAR $\gamma)$. I. Biol. Chem. 270: 12953-12956.

Lekstrom-Himes, J. and K.G. Xanthopoulos. 1998. Biological role of the CCAAT/enhancer-binding protein family of transcription factors. J. Biol. Chem. 273: 28545-28548.

Leo, C. and J.D. Chen. 2000. The SRC family of nuclear receptor coactivators. Gene 245: 1-11.

Lin, F.T. and M.D. Lane. 1992. Antisense CCAAT/enhancerbinding protein RNA suppresses coordinate gene expression and triglyceride accumulation during differentiation of 3T3L1 preadipocytes. Genes \& Dev. 6: 533-544.

- 1994. CCAAT/enhancer binding protein alpha is sufficient to initiate the 3T3-L1 adipocyte differentiation program. Proc. Natl. Acad. Sci. 91: 8757-8761.

Lin, F.T., O.A. MacDougald, A.M. Diehl, and M.D. Lane. 1993. A $30-\mathrm{kDa}$ alternative translation product of the CCAAT/ enhancer binding protein alpha message: Transcriptional activator lacking antimitotic activity. Proc. Nat1. Acad. Sci. 90: 9606-9610.

Lowell, B.B. and J.S. Flier. 1997. Brown adipose tissue, $\beta 3$-adrenergic receptors, and obesity. Annu. Rev. Med. 48: 307316.

MacDougald, O.A. and M.D. Lane. 1995. Transcriptional regulation of gene expression during adipocyte differentiation. Annu. Rev. Biochem. 64: 345-373.

Mandrup, S. and M.D. Lane. 1997. Regulating adipogenesis. J. Biol. Chem. 272: 5367-5370.

Mansen, A., H. Guardiola-Diaz, J. Rafter, C. Branting, and J.A. Gustafsson. 1996. Expression of the peroxisome proliferatoractivated receptor (PPAR) in the mouse colonic mucosa. Biochem. Biophys. Res. Comm. 222: 844-851.

Michael, L.F., M.A. Lazar, and C.R. Mendelson. 1997. Peroxisome proliferator-activated receptor $\gamma 1$ expression is induced during cyclic adenosine monophosphate-stimulated differentiation of alveolar type II pneumocytes. Endocrinology 138: 3695-3703.

Miles, P.D., Y. Barak, W. He, R.M. Evans, and J.M. Olefsky. 2000. Improved insulin-sensitivity in mice heterozygous for PPAR-gamma deficiency. J. Clin. Invest. 105: 287-292.

Mink, S., B. Haenig, and K.H. Klempnauer. 1997. Interaction and functional collaboration of p300 and C/EBP $\beta$. Mol. Cell. Biol. 17: 6609-6617.

Moitra, J.L., M.M. Mason, M. Olive, D. Krylor, O. Gavrilova, B. Marcus-Samuels, L. Feigenbaum, E. Lee, T. Aoyama, M. Eckhaus, M.L. Reitman, and C. Vinson. 1998. Life without white fat: A transgenic mouse. Genes \& Dev. 12: 3168-3181.
Morimoto, C., T. Tsujita, and H. Okuda. 1997. Norepinephrineinduced lipolysis in rat fat cells from visceral and subcutaneous sites: Role of hormone-sensitive lipase and lipid droplets. J. Lipid Res. 38: 132-138.

Morrison, R.F. and S.R. Farmer. 1999. Role of PPAR $\gamma$ in regulating a cascade expression of cyclin-dependent kinase inhibitors, p18(INK4c), and p21(Waf1/Cip1), during adipogenesis. J. Biol. Chem. 274: 17088-17097.

Mueller, E., P. Sarraf, P. Tontonoz, R.M. Evans, K.J. Martin, M. Zhang, C. Fletcher, S. Singer, and B.M. Spiegelman. 1998. Terminal differentiation of human breast cancer through PPAR $\gamma$. Mol. Cell 1: 465-470.

Must, A., J. Spadano, E.H. Coakley, A.E. Field, G. Colditz, and W.H. Dietz. 1999. The disease burden associated with overweight and obesity. JAMA 282: 1523-1529.

Naar, A.M., P.A. Beaurang, S. Zhou, S. Abraham, W. Solomon, and R. Tjian. 1999. Composite co-activator ARC mediates chromatin-directed transcriptional activation. Nature 398: 828-832.

Negrel, R., P. Grimaldi, and G. Ailhaud. 1978. Establishment of a preadipocyte clonal cell line from epididymal fat pad of $o b / o b$ mouse that responds to insulin and to lipolytic hormones. Proc. Nat1. Acad. Sci. 75: 6054-6058.

Oberfield, J.L., J.L. Collins, C.P. Holmes, D.M. Goreham, J.P. Cooper, J.E. Cobb, J.M. Lenhard, E.A. Hull-Ryde, C.P. Mohr, S.G. Blanchard et al. 1999. A peroxisome proliferator-activated receptor gamma ligand inhibits adipocyte differentiation. Proc. Nat1. Acad. Sci. 96: 6102-6106.

Ostman, J., P. Arner, P. Engfeldt, and L. Kager. 1979. Regional differences in the control of lipolysis in human adipose tissue. Metabolism 28: 1198-1205.

Pairault, J. and H. Green. 1979. A study of the adipose conversion of suspended 3T3 cells by using glycerophosphate dehydrogenase as a differentiation marker. Proc. Natl. Acad. Sci. 76: 5138-5142.

Park, E.A., W.J. Roesler, J. Liu, D.J. Klemm, A.L. Gurney, J.D. Thatcher, A. Friedman, and R.W. Hanson. 1990. The role of the CAAT/enhancer-binding protein in the transcriptional regulation of the gene for phosphoenolpyruvate carboxykinase (GTP). Mol. Cell. Biol. 10: 6264-6272.

Pittenger, M.F., A.M. Mackay, S.C. Beck, R.K. Jaiswal, R. Douglas, J.D. Mosca, M.A. Moorman, D.W. Simonetti, S. Craig, and D.R. Marshak. 1999. Multilineage potential of adult human mesenchymal stem cells. Science 284: 143-147.

Puigserver, P., J. Ribot, F. Serra, M. Gianotti, M.L. Bonet, B. Nadal-Ginard, and A. Palou. 1998a. Involvement of the retinoblastoma protein in brown and white adipocyte cell differentiation: Functional and physical association with the adipogenic transcription factor C/EBP $\alpha$. Eur. I. Cell Biol. 77: 117-123.

Puigserver, P., Z. Wu, C.W. Park, R. Graves, M. Wright, and B.M. Spiegelman. 1998b. A cold-inducible coactivator of nuclear receptors linked to adaptive thermogenesis. Cell 92: 829-839.

Puigserver, P., G. Adelmant, Z. Wu, M. Fan, J. Xu, B. O'Malley, and B.M. Spiegelman. 1999. Activation of PPAR $\gamma$ coactivator-1 through transcription factor docking. Science 286: $1368-1371$.

Rachez, C., B.D. Lemon, Z. Suldan, V. Bromleigh, M. Gamble, A.M. Naar, H. Erdjument-Bromage, P. Tempst, and L.P. Freedman. 1999. Ligand-dependent transcription activation by nuclear receptors requires the DRIP complex. Nature 398: 824-828.

Reaven, G.M. 1988. Role of insulin resistance in human disease. Diabetes 37: 1595-1607.

Reusch, J.E., L.A. Colton, and D.J. Klemm. 2000. CREB activa- 
tion induces adipogenesis in 3T3-L1 cells. Mol. Cell. Biol. 20: $1008-1020$.

Richon, V.M., R.E. Lyle, and R.E. McGehee, Jr. 1997. Regulation and expression of retinoblastoma proteins p107 and p130 during 3T3-L1 adipocyte differentiation. J. Biol. Chem. 272: $10117-10124$.

Ron, D. and J. Habener. 1992. CHOP, a novel developmentally regulated nuclear protein that dimerizes with transcription factors C/EBP and LAP and functions as a dominant-negative inhibitor of gene transcription. Genes \& Dev. 6: 439453.

Rosen, E.D., P. Sarraf, A.E. Troy, G. Bradwin, K. Moore, D.S. Milstone, B.M. Spiegelman, and R.M. Mortensen. 1999. PPAR gamma is required for the differentiation of adipose tissue in vivo and in vitro. Mol. Cell 4: 611-617.

Rossi, A., P. Kapahi, G. Natoli, T. Takahashi, Y. Chen, M. Karin, and M.G. Santoro. 2000. Anti-inflammatory cyclopentenone prostaglandins are direct inhibitors of IкB kinase. $\mathrm{Na}$ ture 403: 103-108.

Sandouk, T., D. Reda, and C. Hofman. 1993. Antidiabetic agent pioglitazone enhances adipocyte differentiation of 3T3F442A cells. Am. J. Physiol. 264: C1600-C1608.

Sarraf, P., E. Mueller, D. Jones, F.J. King, D.J. DeAngelo, J.B. Partridge, S.A. Holden, L.B. Chen, S. Singer, C. Fletcher, and B.M. Spiegelman. 1998. Differentiation and reversal of malignant changes in colon cancer through PPAR $\gamma$. Nat. Med. 4: 1046-1052.

Shao, D. and M.A. Lazar. 1997. Peroxisome proliferator activated receptor gamma, CCAAT/enhancer-binding protein alpha, and cell cycle status regulate the commitment to adipocyte differentiation. J. Biol. Chem. 272: 21473-21478.

Shimano, H., J.D. Horton, I. Shimomura, R.E. Hammer, M.S. Brown, and J.L. Goldstein. 1997a. Isoform 1c of sterol regulatory element binding protein is less active than isoform 1a in livers of transgenic mice and in cultured cells. J. Clin. Invest. 99: 846-854.

Shimano, H., I. Shimomura, R.E. Hammer, J. Herz, J.L. Goldstein, M.S. Brown, and J.D. Horton. 1997b. Elevated levels of SREBP-2 and cholesterol synthesis in livers of mice homozygous for a targeted disruption of the SREBP-1 gene. J. Clin. Invest. 100: 2115-2124.

Shimano, H., N. Yahagi, M. Amemiya-Kudo, A.H. Hasty, J. Osuga, Y. Tamura, F. Shionoiri, Y. Iizuka, K. Ohashi, K. Harada et al. 1999. Sterol regulatory element-binding protein-1 as a key transcription factor for nutritional induction of lipogenic enzyme genes. J. Biol. Chem. 274: 35832-35839.

Shimomura, I., H. Shimano, J.D. Horton, J.L. Goldstein, and M.S. Brown. 1997. Differential expression of exons 1a and 1c in mRNAs for sterol regulatory element binding protein-1 in human and mouse organs and cultured cells. J. Clin. Invest. 99: $838-845$.

Shimomura, I., R.E. Hammer, J.A. Richardson, S. Ikemoto, Y. Bashmakov, J.L. Goldstein, and M.S. Brown. 1998. Insulin resistance and diabetes mellitus in transgenic mice expressing nuclear SREBP-1c in adipose tissue: Model for congenital generalized lipodystrophy. Genes \& Dev. 12: 3182-3194.

Shimomura, I., Y. Bashmakov, S. Ikemoto, J.D. Horton, M.S. Brown, and J.L. Goldstein. 1999a. Insulin selectively increases SREBP-1c mRNA in the livers of rats with streptozotocin-induced diabetes. Proc. Natl. Acad. Sci. 96: 1365613661.

Shimomura, I., R.E. Hammer, S. Ikemoto, M.S. Brown, and J.L. Goldstein. 1999b. Leptin reverses insulin resistance and diabetes mellitus in mice with congenital lipodystrophy. $\mathrm{Na}$ ture 401: 73-76.

Sladek, R., J.A. Bader, and V. Giguere. 1997. The orphan nuclear receptor estrogen-related receptor alpha is a transcriptional regulator of the human medium-chain acyl coenzyme A dehydrogenase gene. Mol. Cell. Biol. 17: 5400-5409.

Solomon, C., J.H. White, and R. Kremer. 1999. Mitogen-activated protein kinase inhibits 1,25-dihydroxyvitamin D3-dependent signal transduction by phosphorylating human retinoid X receptor $\alpha$. J. Clin. Invest. 103: 1729-1735.

Spiegelman, B.M., L. Choy, G. Hotamisligil, R.A. Graves, and P. Tontonoz. 1993. Regulation of adipocyte gene expression in differentiation and syndromes of obesity/diabetes. J. Biol. Chem. 268: 6823-6826.

Stephens, J.M., R.F. Morrison, Z. Wu, and S.R. Farmer. 1999. PPAR $\gamma$ ligand-dependent induction of STAT1, STAT5A, and STAT5B during adipogenesis. Biochem. Biophys. Res. Commun. 262: 216-222.

Stewart, W.C., R.F. Morrison, S.L. Young, and J.M. Stephens. 1999. Regulation of signal transducers and activators of transcription (STATs) by effectors of adipogenesis: Coordinate regulation of STATs $1,5 \mathrm{~A}$, and $5 \mathrm{~B}$ with peroxisome proliferator-activated receptor-gamma and C/AAAT enhancer binding protein-alpha. Biochim. Biophys. Acta 1452: 188196.

Tai, T.A.C., C. Jennermann, K.K. Brown, B.B. Oliver, M.A. MacGinnitie, W.O. Wilkison, H.R. Brown, J.M. Lehmann, S.A. Kliewer, D.C. Morris, and R.A. Graves. 1996. Activation of the nuclear receptor peroxisome proliferator-activated receptor gamma promotes brown adipocyte differentiation. J. Biol. Chem. 271: 29909-29914.

Tanaka, T., N. Yoshida, T. Kishimoto, and S. Akira. 1997. Defective adipocyte differentiation in mice lacking the C/EBP $\beta$ and/or C/EBPS gene. EMBO T. 16: 7432-7443.

Taylor, S.M. and P.A. Jones. 1979. Multiple new phenotypes induced in 10T1/2 and 3T3 cells treated with 5-azacytidine. Cell 17: 771-779.

Tang, Q.Q., M.S. Jiang, and M.D. Lane. 1999. Repressive effect of Sp1 on the C/EBP alpha gene promoter: Role in adipocyte differentiation. Mol. Cell Biol. 19: 4855-4865.

Timchenko, N.A., M. Wilde, M. Nakanishi, J.R. Smith, and G.J. Darlington. 1996. CCAAT/enhancer-binding protein alpha (C/EBP alpha) inhibits cell proliferation through the p21 (WAF-1/CIP-1/SDI-1) protein. Genes \& Dev. 10: 804-815.

Tontonoz, P., J.B. Kim, R.A. Graves, and B.M. Spiegelman. 1993. ADD1: A novel helix-loop-helix transcription factor associated with adipocyte determination and differentiation. Mol. Cell. Biol. 13: 4753-4759.

Tontonoz, P., R.A. Graves, A.I. Budavari, H. Erdjument-Bromage, M. Lui, E. Hu, P. Tempst, and B.M. Spiegelman. 1994a. Adipocyte-specific transcription factor ARF6 is a heterodimeric complex of two nuclear hormone receptors, PPAR $\gamma$ and RXR $\alpha$. Nucleic Acids Res. 22: 5628-5634.

Tontonoz, P., E. Hu, R.A. Graves, A.I. Budavari, and B.M. Spiegelman. 1994b. mPPAR $\gamma 2$ : Tissue-specific regulator of an adipocyte enhancer. Genes \& Dev. 8: 1224-1234.

Tontonoz, P., E. Hu, and B.M. Spiegelman. 1994c. Stimulation of adipogenesis in fibroblasts by PPAR $\gamma 2$, a lipid-activated transcription factor. Cell 79: 1147-1156.

Tontonoz, P., E. Hu, J. Devine, E.G. Beale, and B.M. Spiegelman. 1995. PPAR $\gamma 2$ regulates adipose expression of the phosphoenolpyruvate carboxykinase gene. Mol. Cell. Biol. 15: 351357.

Tontonoz, P., S. Singer, B.M. Forman, P. Sarraf, J.A. Fletcher, C.D. Fletcher, R.P. Brun, E. Mueller, S. Altiok, H. Oppenheim, R.M. Evans, and B.M. Spiegelman. 1997. Terminal differentiation of human liposarcoma cells induced by ligands for peroxisome proliferator-activated receptor gamma and the retinoid X receptor. Proc. Natl. Acad. Sci. 94: 237-241. 
Tontonoz, P., L. Nagy, J.G.A. Alvarez, V.A. Thomazy, and R.M. Evans. 1998. PPAR $\gamma$ promotes monocyte/macrophage differentiation and uptake of oxidized LDL. Cell 93: 241-252.

Umek, R.M., A.D. Friedman, and S.L. McKnight. 1991. CCAAT-enhancer binding protein: A component of a differentiation switch. Science 251: 288-292.

Wang, N.D., M.J. Finegold, A. Bradley, C.N. Ou, S.V. Abdelsayed, M.D. Wilde, L.R. Taylor, D.R. Wilson, and G.J. Darlington. 1995. Impaired energy homeostasis in C/EBP alpha knockout mice. Science 269: 1108-1112.

Wright, H.M., C.B. Clish, T. Mikami, S. Hauser, K. Yanagi, R. Hiramatsu, C.N. Serhan, and B.M. Spiegelman. 2000. A synthetic antagonist for the peroxisome proliferator-activated receptor gamma inhibits adipocyte differentiation. J. Biol. Chem. 275: 1873-1877.

Wu, Z., Y. Xie, N.L.R. Bucher, and S.R. Farmer. 1995. Conditional ectopic expression of C/EBP $\beta$ in NIH-3T3 cells induces PPAR $\gamma$ and stimulates adipogenesis. Genes \& Dev. 9: 2350-2363.

Wu, Z., N.L.R. Bucher, and S.R. Farmer. 1996. Induction of peroxisome proliferator-activated receptor $\gamma$ during the conversion of 3T3 fibroblasts into adipocytes is mediated by C/EBP $\beta, \mathrm{C} / \mathrm{EBP} \delta$, and glucocorticoids. Mol. Cell. Biol. 16: 4128-4136.

Wu, Z., P. Puigserver, U. Andersson, C. Zhang, G. Adelmant, V. Mootha, A. Troy, S. Cinti, B. Lowell, R.C. Scarpulla, and B.M. Spiegelman. 1999a. Mechanisms controlling mitochondrial biogenesis and respiration through the thermogenic coactivator PGC-1. Cell 98: 115-124.

Wu, Z., E.D. Rosen, R. Brun, S. Hauser, G. Adelmant, A.E. Troy, C. McKeon, G.J. Darlington, and B.M. Spiegelman. 1999b. Cross-regulation of $\mathrm{C} / \mathrm{EBP} \alpha$ and PPAR $\gamma$ controls the transcriptional pathway of adipogenesis and insulin sensitivity. Mol. Cell 3: 151-158.

Xu, J., Y. Qiu, F.J. DeMayo, S.Y. Tsai, M.-J. Tsai, and B.W. O'Malley. 1998. Partial hormone resistance in mice with disruption of the steroid receptor coactivator-1 (SRC-1) gene. Science 279: 1922-1925.

Yamanaka, R., C. Barlow, J. Lekstrom-Himes, L.H. Castilla, P.P. Liu, M. Eckhaus, T. Decker, A. Wynshaw-Boris, and K.G. Xanthopoulos. 1997. Impaired granulopoiesis, myelodysplasia, and early lethality in CCAAT/enhancer binding protein epsilon-deficient mice. Proc. Natl. Acad. Sci. 94: 1318713192.

Yao, T.P., G. Ku, N. Zhou, R. Scully, and D.M. Livingston. 1996. The nuclear hormone receptor coactivator SRC-1 is a specific target of p300. Proc. Natl. Acad. Sci. 93: 10626-10631.

Yao, T.P., S.P. Oh, M. Fuchs, N.D. Zhou, L.E. Ch'ng, D. Newsome, R.T. Bronson, E. Li, D.M. Livingston, and R. Eckner. 1998. Gene dosage-dependent embryonic development and proliferation defects in mice lacking the transcriptional integrator p300. Cell 93: 361-372.

Yeh, W.C., Z. Cao, M. Classon, and S.L. McKnight. 1995. Cascade regulation of terminal adipocyte differentiation by three members of the C/EBP family of leucine zipper proteins. Genes \& Dev. 15: 168-181.

Yokoyama, C., X. Wang, M.R. Briggs, A. Admon, J. Wu, X. Hua, J.L. Goldstein, and M.S. Brown. 1993. SREBP-1, a basic-helixloop-helix-leucine zipper protein that controls transcription of the low density lipoprotein receptor gene. Cell 75: 187197.

Zhang, D.E., P. Zhang, N.D. Wang, C.J. Hetherington, G.J. Darlington, and D.G. Tenen. 1997. Absence of granulocyte colony-stimulating factor signaling and neutrophil development in CCAAT enhancer binding protein alpha-deficient mice. Proc. Nat1. Acad. Sci. 94: 569-574.
Zhu, Y., K. Alvares, Q. Huang, M.S. Rao, and J.K. Reddy. 1993. Cloning of a new member of the peroxisome proliferatoractivated receptor gene family from mouse liver. J. Biol. Chem. 268: 26817-26820.

Zhu, Y., C. Qi, J.R. Korenberg, X.-N. Chen, D. Noya, M.S. Rao, and J.K. Reddy. 1995. Structural organization of mouse peroxisome proliferator-activated receptor $\gamma(\operatorname{mPPAR} \gamma)$ gene: Alternative promoter use and different splicing yield two mPPARy isoforms. Proc. Natl. Acad. Sci. 92: 7921-7925.

Zhu, Y., C. Qi, S. Jain, M.S. Rao, and J.K. Reddy. 1997. Isolation and characterization of $\mathrm{PBP}$, a protein that interacts with peroxisome proliferator-activated receptor. J. Biol. Chem. 272: 25500-25506.

Zhu, Y., C. Qi, Y. Jia, J.S. Nye, M.S. Rao, and J.K. Reddy. 2000. Deletion of the gene for nuclear receptor coactivator PBP results in embryonic lethality. J. Biol. Chem. (in press). 


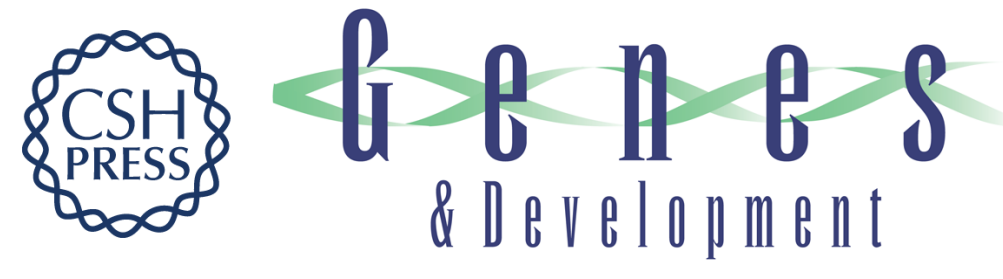

\section{Transcriptional regulation of adipogenesis}

Evan D. Rosen, Christopher J. Walkey, Pere Puigserver, et al.

Genes Dev. 2000, 14:

Access the most recent version at doi:10.1101/gad.14.11.1293

References This article cites 147 articles, 90 of which can be accessed free at: http://genesdev.cshlp.org/content/14/11/1293.full.html\#ref-list-1

License

Email Alerting Receive free email alerts when new articles cite this article - sign up in the box at the top Service right corner of the article or click here.

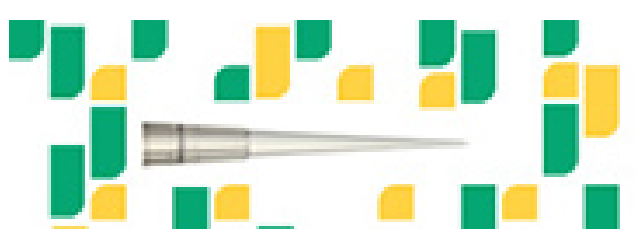

Focused on your science. 